Published in "Science of The Total Environment 658(): 1614-1629, 2019"

which should be cited to refer to this work.

\title{
Litter decomposition driven by soil fauna, plant diversity and soil management in urban gardens
}

\author{
Simon Trescha,b,c,*, David Frey ${ }^{\mathrm{c}, \mathrm{d}}$, Renée-Claire Le Bayon ${ }^{\mathrm{a}}$, Andrea Zanetta ${ }^{\mathrm{c}, \mathrm{e}}$, Frank Raschef \\ Andreas Fliessbach ${ }^{\mathrm{b}}$, Marco Moretti ${ }^{\mathrm{c}}$ \\ a University of Neuchâtel, Institute of Biology, Functional Ecology Laboratory, Rue Emile-Argand 11, Neuchâtel 2000, Switzerland \\ ${ }^{\mathrm{b}}$ Research Institute of Organic Agriculture (FiBL), Department of Soil Sciences, Ackerstrasse 113, Frick 5070, Switzerland \\ 'Swiss Federal Research Institute WSL, Biodiversity and Conservation Biology, Zuercherstrasse 111, Birmensdorf 8903, Switzerland \\ ${ }^{\mathrm{d}}$ ETH, Department of Environmental System Science, Institute of Terrestrial Ecosystems, Universitaetstrasse 16, Zurich 8092, Switzerland \\ e University of Fribourg, Department of Biology, Chemin du musée 10, Fribourg 1700, Switzerland \\ ${ }^{\mathrm{f}}$ Institute of Agricultural Sciences in the Tropics (Hans-Ruthenberg-Institute), University of Hohenheim, Garbenstr. 13, Stuttgart 70599, Germany
}

\section{H I G H L I G H T S}

- Garden management affected both fauna diversity and litter decomposition

- Garden land-use types had the biggest effect on litter decomposition

- Soil fauna species richness covaried positively with decomposition rates

- Plant diversity increased fauna diversity and microbial activity - Urbanisation density was positively
associated with litter decomposition

MidDRIFTS analysis revealed variance in litter residue quality after decomposition

\section{G R A P H I C A L A B S T R A C T}

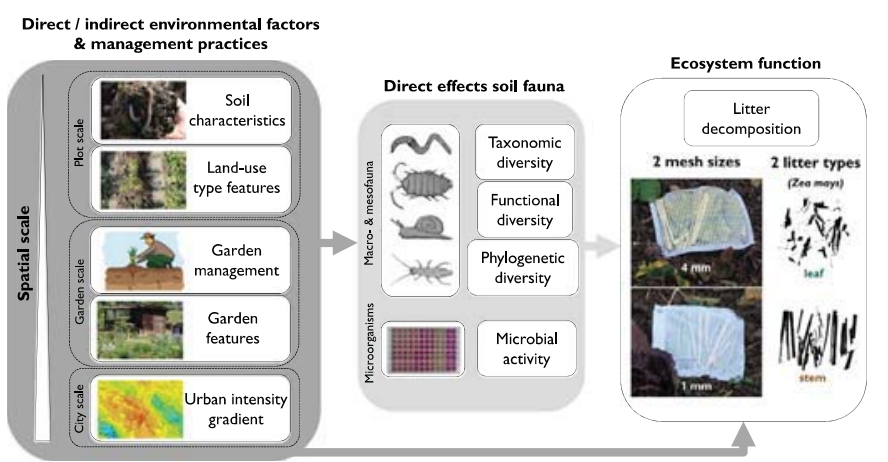

\begin{abstract}
A B S T R A C T
In the face of growing urban densification, green spaces in cities, such as gardens, are increasingly important for biodiversity and ecosystem services. However, the influences of urban green space management on biodiversity and ecosystem functioning (BEF) relationships is poorly understood. We investigated the relationship between soil fauna and litter decomposition in 170 urban garden sites along a gradient of urbanisation intensity in the city of Zurich, $\mathrm{CH}$. We used litter bags of 1 and $4 \mathrm{~mm}$ mesh size to evaluate the contribution of soil meso- and macrofauna on litter decomposition. By using multilevel structural equation models (SEM), we investigated direct and indirect environmental effects and management practices on litter decomposition and litter residue quality. We evaluated the role of taxonomic, functional and phylogenetic diversity of soil fauna species on litter decomposition, based on a sample of 120 species (81,007 individuals; 39 collembola, 18 earthworm, 16 isopod, 47 gastropod species). We found highest litter decomposition rates using $4 \mathrm{~mm}$ mesh size litter bags, highlighting the importance of soil macrofauna. Urban warming, a proxy for urbanisation intensity, covaried positively, whereas soil disturbances, such as intensive soil and crop management, were negatively correlated with decomposition rates. Interestingly, soil fauna species
\end{abstract}

\footnotetext{
* Corresponding author at: University of Neuchâtel, Institute of Biology, Functional Ecology Laboratory, Rue Emile-Argand 11, Neuchâtel 2000, Switzerland. E-mail address: simon.tresch@fibl.org (S. Tresch).
} 
Keywords:

Urban gardening

Litter bag decomposition

Biodiversity ecosystem functioning (BEF)

Urban ecosystem services

Urban soil biodiversity

MidDRIFTS analysis

Urban warming richness decreased, with the exception of gastropods, and soil fauna abundance increased with urban warming. Our data also show that plant species richness positively affected litter decomposition by increasing soil fauna species richness and microbial activity. A multivariate analysis of organic compounds in litter residues confirmed the importance of soil fauna species richness and garden management on litter decomposition processes. Overall, we showed, that also in intensively managed urban green spaces, such as gardens, biodiversity of plants and soil fauna drives key ecosystem processes. Urban planning strategies that integrate soil protecting management practices may help to maintain important ecosystem services in this heavily used urban environment.

\section{Introduction}

Anthropogenic activities have an unprecedented impact on ecosystems worldwide (Butchart et al., 2010). Globally, over 60\% of the world's ecosystems are degraded or managed unsustainably (UN FAO, 2011), causing the loss of biodiversity across the globe (Ceballos et al., 2015). This may drastically accelerate the rates of change in ecosystem processes (Cardinale et al., 2011), thereby altering the productivity and regeneration capacity of ecosystems (Wardle et al., 2011).

One example of a global change driver is urbanisation. Nowadays, the majority of people live in cities (54\% in 2014) with an expected growth reaching $66 \%$ within the next three decades (United Nations, 2015). Urban areas are expanding faster than any other land-use type (Hansen et al., 2005). This increasing urbanisation has a major influence on the environment (Grimm et al., 2008) but also on local processes (Groffman et al., 2014), by altering biogeochemistry, hydrology and biodiversity (Groffman et al., 2017).

Cities are unique ecosystems (Kaye et al., 2006) consisting of complex mosaics of different land-use types (Zhou et al., 2017). As anthropogenic ecosystems, they provide an ideal opportunity to investigate the influence of human activities on biodiversity and ecosystem services (Aronson et al., 2016). Overall, the expanding urbanisation is expected to reduce species diversity and abundance, increase biotic homogenisation and to negatively affect species interactions with likely negative consequences on key ecological processes (Foley et al., 2005; McKinney, 2008). On the other hand, depending on the intensity of urbanisation, cities can harbour a remarkably high biodiversity (Godefroid and Koedam, 2007): even including endangered native species (Ives et al., 2016), which may even exceed the rural surroundings (Kühn et al., 2004). A possible explanation for this pattern is the high spatial and environmental heterogeneity in cities (e.g. Rebele, 1994; Sattler et al., 2010). In this respect, urban green spaces can offer conservation opportunities (Mata et al., 2017) and benefits for humans, as biodiverse urban green spaces are known to improve well-being and health of residents (Keniger et al., 2013).

While green spaces such as gardens are becoming important refuges for native biodiversity in many cities (Goddard et al., 2010), soil sealing is steadily increasing due to the demand for infrastructure (Benton et al., 2003). Besides their role for biodiversity conservation, urban gardens also provide key ecosystem services (Zhu et al., 2018), which are otherwise negatively affected by urbanisation (Ziter, 2016). These services include climate and water regulation along with recreation, health and social cohesion (Bell et al., 2016; Haase et al., 2014). However, there are still few studies about the benefits of urban gardens (Cabral et al., 2017), despite the fact that they cover large proportions of urban green spaces in many cities (Loram et al., 2007).
The importance of biodiversity in maintaining ecosystem services is getting recognised (Hector and Bagchi, 2007), however, our understanding of the underlying mechanisms remains limited. This is in part due to the lack of real world observations (Gossner et al., 2016), especially in human dominated ecosystems such as cities (Isbell et al., 2017; Schwarz et al., 2017). Overall, there is substantial experimental evidence of a positive influence of biodiversity on the functioning of ecosystems (Cardinale et al., 2011; Duffy, 2009). This positive influence is often derived from studies with productivity as an ecosystem service (Caruso et al., 2018; Vogel et al., 2013), but has also been found for ecosystem functions such as litter decomposition (Allan et al., 2013; Weisser et al., 2017).

Decomposition of organic matter is one of the central functions of ecosystems (Swift et al., 1979) and is mainly driven by environmental conditions such as climate or soil properties, litter quality, and the composition of decomposer species communities (Cadisch and Giller, 1997; McClaugherty and Berg, 2011; Swift et al., 1979). A loss or change of decomposer diversity and species composition is likely to alter decomposition dynamics (Hättenschwiler and Gasser, 2005; Heemsbergen, 2004), but its extent and consequences remain difficult to predict (García-Palacios et al., 2016a; Hättenschwiler et al., 2005; Hooper et al., 2005). The majority of studies has analysed the effect of different litter types on decomposition (Patoine et al., 2017) and has shown a mean positive effect of leaf litter species diversity on litter mass loss across biomes (Handa et al., 2014). Nielsen et al. (2011) explored the relationship between soil fauna and ecosystem functions relevant for C cycling. In 11 out of 15 studies, they reported a positive relationship between soil fauna species richness and decomposition. Yet, the role of soil fauna on litter decomposition, including not only taxonomic but also functional or phylogenetic metrics, remains mostly unknown (Patoine et al., 2017), especially in urban ecosystems (Schwarz et al., 2017), were environmental conditions and management practices can be profoundly different compared with rural areas (Gaston et al., 2010).

The complex urban soils are the foundation of a range of functions and services such as supporting (soil formation, nutrient cycling or habitat space), regulating (climate, floods and water), carrying or cultural services (Rawlins et al., 2015; Tresch et al., 2018a), which are essential for liveable and resilient cities (Elmqvist et al., 2015). Urban soils are influenced by several factors such as compaction, urban warming - the elevation in urban relative to non-urban temperatures (Oke, 1995) - increased precipitation (Gilbert, 1989), modified hydrology (Francis, 2014) and increased deposition of pollutants and nitrogen (Kaye et al., 2006). Their soil properties and biogeochemical cycles are also altered directly by anthropogenic activities such as construction work (Lorenz and Lal, 2009).

Nevertheless, in the case of urban garden soils, specific garden management practices can increase soil quality indices, such as 
organic matter content and biological activity, over the long term (Edmondson et al., 2014; Tresch et al., 2018a), if organic cultivation rules without chemical fertilisation and pesticides have been implemented (Bretzel et al., 2018). Thus, it seems probable that some urban soils contains higher organic carbon contents than those in rural landscapes (Edmondson et al., 2012).

While above-ground BEF relationships are often shaped by an interaction of local-scale (e.g. vegetation structure ) and landscapescale factors (Angold et al., 2006; Frey et al., 2018a), our understanding of how such multi-scale factors affect the belowground BEF relationships is still limited (Lin and Egerer, 2018). For example, recent studies of ecosystems services rarely addressed the high spatial heterogeneity and complexity of urban soils (Ziter and Turner, 2018), and neither consider the variety of direct and indirect anthropogenic influences across spatial scales (Enloe et al., 2015), nor the role of different aspects of biodiversity (Schwarz et al., 2017). An assessment of BEF relationships in cities therefore requires integrated analytical tools, such as structural equation modelling (SEM), that allow for a causal understanding of direct and indirect at different spatial scales (Eisenhauer et al., 2015), especially including human components (Isbell et al., 2017).

In this study, we chose litter decomposition as model ecosystem function, due to its importance in maintaining soil quality in urban gardens (Schram-Bijkerk et al., 2018) and because of the lack of studies analysing the effect of urbanisation on litter decomposition - (Dorendorf et al., 2015). We investigated direct and indirect effects of environmental factors and management practices on litter decomposition along an urban intensity gradient, which was measured as the local temperature increase due to urban warming. The objectives of our study were to investigate the following three aspects: (i) the direct effects of abiotic and biotic factors on litter mass loss, (ii) the direct and indirect effects of soil characteristics, garden management - and urban warming on soil fauna and litter decomposition and (iii) to analyse which factors influenced litter residue quality after decomposition. Overall, we hypothesised that factors at plot and garden scale have a greater impact on soil biodiversity and litter decompo- sition than at the city scale, because of the dominant management influence on soil fauna and functioning (Lavelle et al., 2006).

\section{Material and methods}

\subsection{Study area and site selection}

The study took place in urban gardens in the city of Zurich, Switzerland (Fig. 1). Zurich lies in the temperate climate zone with mean annual temperature of $9.3^{\circ} \mathrm{C}(1981-2010)$ and mean annual precipitation of $1134 \mathrm{~mm}$ (MeteoSwiss, 2017). With an area of approximately $92 \mathrm{~km}^{2}$ and a population of 0.4 million citizen it belongs to the globally most common city class (United Nations, 2015) and is therefore an ideal system to study BEF relationships in urban environments.

We selected 42 allotment and 43 home gardens (Fig. 1), representing the two most common urban garden types worldwide (Lin et al., 2017). Allotment gardens are cultivated lots of land in an urban area, normally used for recreational purposes or the cultivation of fruits, vegetables and flowers (Bell et al., 2016). The allotment gardens in Zurich mainly belong to the city municipality. The first lots were established in 1907 (Bell et al., 2016), succeeding a history of self-supplying citizen gardens dating back to the 16th century (Christl et al., 2004). Home gardens are privately owned garden lots belonging to single-occupancy and terraced houses. They cover $25 \%$ of the total urban green space of Zurich, while allotments only account for 7\% (Grün Stadt Zurich, 2010). Gardens were selected according to a stratified sampling design based on an urban habitat map (Grün Stadt Zurich, 2010) with three independent strata: (i) garden type (private vs. allotment), (ii) garden management (low vs. high vertical vegetation structure and proportion of native plant species) and an (iii) urbanisation intensity gradient, ranging from densely built-up areas to peripheral areas within the city margins of Zurich (Frey et al., 2018b). In each of the 85 urban gardens, we selected two sampling sites $(2 \mathrm{~m} \times 2 \mathrm{~m})$ with contrasting soil

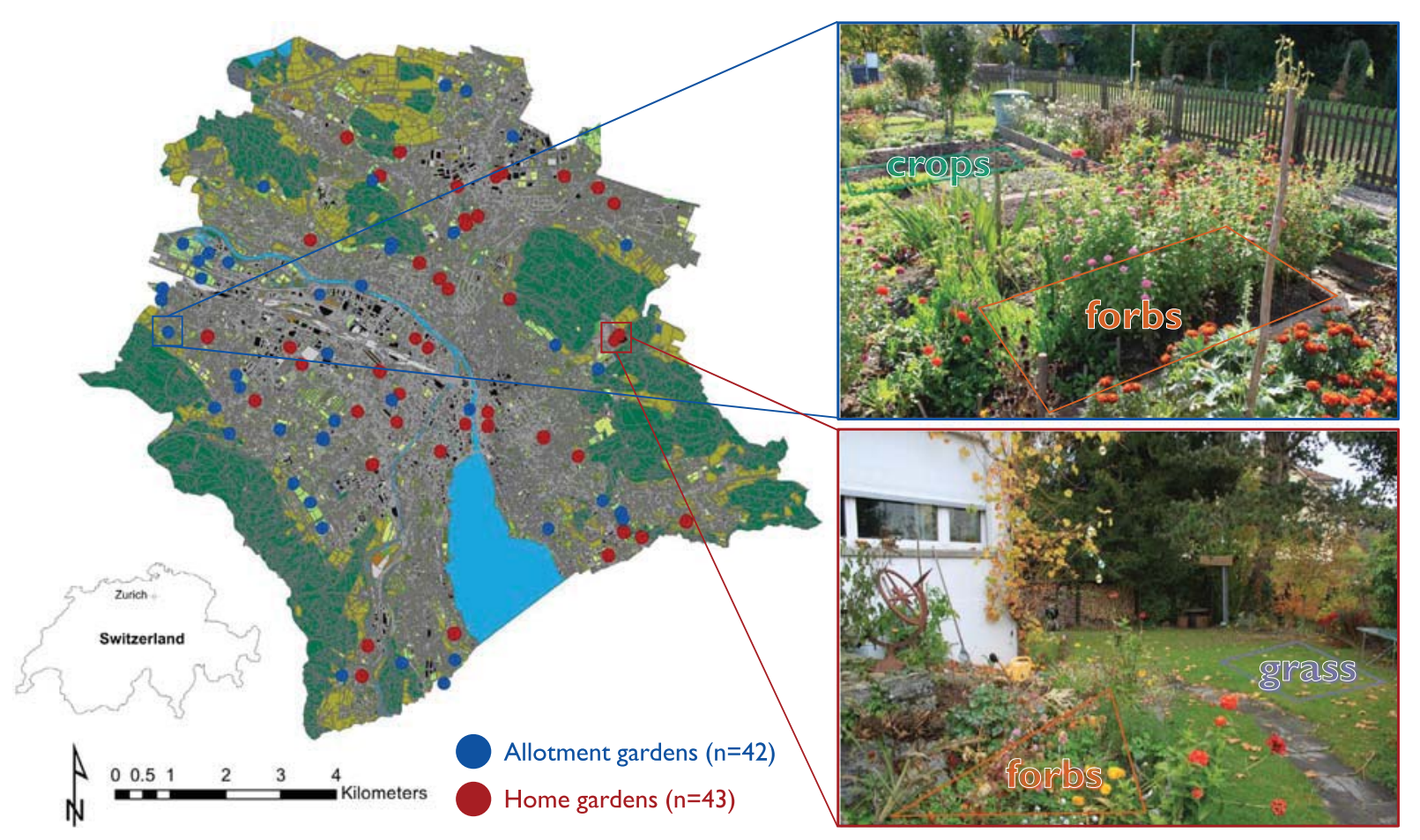

Fig. 1. Typical examples of home (red) and allotment (blue) gardens of Zurich. Within each of the 85 urban gardens, two sampling sites were chosen according to the main garden land-use types: crops, forbs and grass. 
disturbance. All sites $(n=170)$ were associated to one of the common urban land-use types: crops (annual vegetables), forbs (perennial flowers and berries) and grass (lawn and meadows).

\subsection{Litter decomposition experiment}

Litter decomposition was assessed both quantitatively with litter bags and qualitatively with spectroscopy of litter residues. We used litter bags $(18 \mathrm{~cm} \times 18 \mathrm{~cm}$; Finerty et al., 2016) of two mesh sizes ( $1 \mathrm{~mm}$ and $4 \mathrm{~mm}$ ) to evaluate the contribution of macrofauna to litter decomposition. A fine mesh (1 $\mathrm{mm})$ was used on the bottom for both litter bag types to avoid loss of litter material. Litter bag contents were standardised by using $4 \mathrm{~g}$ of oven dried $\left(40^{\circ} \mathrm{C}\right)$ maize (Zea mays L.) leaves with equal proportions of $2 \pm 0.01 \mathrm{~g}$ leaf and $2 \pm 0.01 \mathrm{~g}$ of stem material (i.e. central leaf vein). Maize was absent in all investigated gardens which avoided facilitation effects of decomposition. Leaves and stems of Zea mays L. contrasts in the ratio of carbon to nitrogen (leaf: $18 \pm 0.3$, stem: $71 \pm 3$ ) and also in the leaf tensile strength (leaf: $1.2 \pm 0.06 \mathrm{MNm}^{-2}$, stem: $4.4 \pm 0.3 \mathrm{MNm}^{-2}$ ) and thus in the palatability and accessibility for soil decomposer organisms. Litter traits were measured on ten random samples per litter type following Pérez-Harguindeguy et al. (2013) (Table A.1). In total 340 litter bags ( 2 mesh sizes $\times 2$ sites $\times 85$ gardens; Fig. B. 1 ) were placed on top of the soil for six months (December 2015-May 2016) and the remaining litter was dried $\left(40^{\circ} \mathrm{C}\right)$. Decomposition was expressed as percentage change in litter mass before and after decomposition. Litter residue quality after decomposition was assessed by the composition of functional organic compounds measured by diffuse reflectance Fourier transform mid-infrared spectroscopy (midDRIFTS) following Rasche et al. (2013). For measurement details see Tresch et al. (2018a). We applied midDRIFTS before and after decomposition revealing the biochemical quality of the organic residues (see Table 1).

\subsection{Soil fauna}

\subsubsection{Soil macrofauna}

We sampled gastropods (i.e. snails), isopods (i.e. woodlice) and earthworms as major macrofauna litter decomposers (Briones, 2014). Gastropods and isopods were sampled using a triplet of pitfall traps (70 mm in diameter) as described in Frey et al. (2016). Pitfall traps were filled with $0.2 \%$ Rocima solution (Acima, Buchs, $\mathrm{CH}$ ) and weekly emptied from May 25 to August 18, 2015. Gastropod identification followed (Hausser, 2005), whereas isopods were identified by specialists (see acknowledgements). Earthworms were collected between mid-September and the end of October 2015 using a standardised method combining hand sorting (Bartlett et al., 2010) and mustard solution (0.6\%) extraction (Lawrence and Bowers, 2002). The sampling sites were $0.3 \mathrm{~m} \times 0.3 \mathrm{~m}$ with a depth of $0.3 \mathrm{~m}$. Species identification was done according to Bouché (1977), Sims and Gerard (1999). All decomposers were sampled at the litter bag sites of $2 \mathrm{~m} \times 2 \mathrm{~m}$.

\subsubsection{Soil mesofauna}

Collembola are important micro-arthropods for decomposition in terrestrial ecosystems (Rusek, 1998). They were collected from midNovember until the end of December 2015 during the initial phase of the decomposition experiment. Six replicated undisturbed soil cores ( $5 \mathrm{~cm}$ diameter, $8 \mathrm{~cm}$ length, Eijkelkamp, $\mathrm{NL}$ ) were taken randomly from the topsoil (Querner and Bruckner, 2010) within the $2 \mathrm{~m} \times 2 \mathrm{~m}$ sampling sites. Mesofauna was extracted using a high temperature and moisture gradient MacFadyen extractor with an increasing temperature gradient from 20 to $60^{\circ} \mathrm{C}$ (cf. Table A.2). Three undisturbed soil cores: each of $175 \mathrm{~cm}^{3}$, were pooled together for the extraction period, which lasted one week. Collembola were identified at the species level by experts (see acknowledgements). All soil macro- and mesofauna species were stored in $70 \%$ ethanol and juveniles were not taken into account.

\subsubsection{Biodiversity indices}

2.3.3.1. Taxonomic diversity. There are two principle components of taxonomic diversity: species richness and species evenness, which is how evenly species are distributed within a community (Magurran and McGill, 2011). The calculated indices are soil fauna abundance $(N)$, species richness $(S)$, Shannon diversity index $\left(D_{\text {Shannon }}\right)$ and Shannon evenness $\left(E_{\text {Shannon }}\right)$. Species richness was the total number of soil fauna species observed in each study site and $\mathrm{N}$ the sum of soil fauna abundance on the lowest level of temporal resolution. The abundance was manipulated for the total abundance of gastropods and isopods to represent one week instead of ten weeks due to the sampling of those invertebrates by dividing $\mathrm{N}$ with ten $\left(\frac{N}{10}\right)$. The Shannon diversity index was calculated as $D_{\text {Shannon }}=-\sum_{i=1}^{S} p_{i} \ln p_{i}$, where $\mathrm{p}_{\mathrm{i}}$ represents the proportion of soil fauna abundance belonging to species $i$ and the Shannon evenness was calculated as $E_{\text {Shannon }}=\frac{D_{\text {Shannon }}}{\ln S}$.

2.3.3.2. Functional diversity. Functional diversity indices includes components of richness, evenness and divergences of trait values and their abundances (Villéger et al., 2008). The three components were taken into account by calculating the trait onion peeling (TOP; Fontana et al. (2016)) index, the sum of all convex hulls' areas of a community in the trait space, the trait even distribution index (TED; Fontana et al. (2016)), the regularity in the distribution of species, and the functional dispersion index (FDis; Laliberté and Legendre (2010)), which is the mean distance of species to the centroid of trait distribution, based on standardised trait values ( $m e a n=0$, standard deviation $=1$ ). We used body size as a trait directly connected to the food resource and consumption rate (Bardgett and Wardle, 2010) and the eco-behavioural trait vertical distribution, reflecting functional life forms of soil fauna species (Briones, 2014; Table A.5).

2.3.3.3. Phylogenetic diversity. Four variables related to phylogenetic diversity (Paradis, 2011) were calculated including phylogenetic diversity (PD), the sum of branch lengths, phylogenetic species variability (PSV), the mean of the phylogenetic correlations among

Table 1

Litter residue analysis of contrasting functional organic compounds, selected as midDRIFTS peak measurements modified after Kunlanit et al. (2014).

\begin{tabular}{llll}
\hline Label & Frequency $\left[\mathrm{cm}^{-1}\right]$ & Structural assignment & Quality \\
\hline Labile_A & $2800-3010$ & Aliphatic C - H stretching (Senesi et al., 2003; Stevenson, 1994) & Labile \\
Labile_B & $1915-2200$ & Carbohydrate overtones of C - OH stretching (Janik et al., 2007) & Labile \\
Labile_C & $1094-1147$ & C- OH of aliphatic OH (Tatzber et al., 2010) & Labile \\
Stable_D & $1700-1772$ & C- O stretching of COOH and ketones (Rodriguez, 2011; Stevenson, 1994) & Stable \\
Stable_E & $1620-1700$ & Aromatic COO stretching (Demyan et al., 2012; Nault et al., 2009; Smidt and Meissl, 2007) & Stable \\
Stable_F & $1537-1620$ & C= C of aromatic groups (Duboc et al., 2012) & Stable \\
Stable_G & $1401-1445$ & C- H and N- H aromatic amide II, COO- stretching of some aromatic organic acids & Stable \\
Stable_H & $1296-1350$ & e.g. malonic and or benzoic acids (Stevenson, 1994; Tatzber et al., 2010) & Stable \\
\hline
\end{tabular}


species in the community, phylogenetic species evenness (PSE), which is PSV with relative species abundance, and phylogenetic species richness (PSR), PSV multiplied by S. They were calculated by building a phylogenetic tree ('rotl' package; Michonneau et al. (2016)) with branch lengths ('ape' package; Paradis et al., 2004) based on the open tree of life project (Hinchliff et al., 2015) following (Paradis, 2011).

\subsubsection{Microbial activity}

Soil microbial activity of each litter bag site was quantified by the multiple substrate-induced respiration (MSIR) rate measured with the MicroResp ${ }^{\mathrm{TM}}$ system (Campbell et al., 2003) following Sradnick et al. (2013). A range of 19 different C-substrates, including $\mathrm{H}_{2} \mathrm{O}$, were selected to present a spectrum of root exudates typically occurring in soil, comprising six amino acids, one amino sugar, four sugars, four carboxylic acids, two phenolic acids and one hemicellulose (Campbell et al., 1997). The MSIR was calculated as the sum of all C-substrates respiration values. Details about the C-substrates, calibration and measurement procedure are described in Table A.3.

\subsection{Environmental factors and management practices}

\subsubsection{Soil characteristics}

Soil characteristics at the litter bag sites were quantified as a comprehensive set of soil quality indices (Bünemann et al., 2018), including nine physical (bulk density (BD), pore space volume (PV), stable aggregates (SA), soil texture (clay, sand, silt), water holding capacity (WHC), penetration resistance (PR) and soil depth), nine chemical ( $\mathrm{pH}$, electrical conductivity (EC), nutrients ( $\mathrm{P}, \mathrm{K}, \mathrm{Mg}, \mathrm{Fe}$, $\mathrm{Cu}, \mathrm{Mn}, \mathrm{B})$ ) and ten biological (basal respiration, bacteria, $\mathrm{C}_{\min }, \mathrm{N}_{\min }$, $\mathrm{C}_{\text {mic }}, \mathrm{N}_{\text {mic }}$, DOC, DON, SOC, TON) soil properties as well as nine heavy metals ( $\mathrm{Sb}, \mathrm{As}, \mathrm{Co}, \mathrm{Cu}, \mathrm{Pb}, \mathrm{Ni}, \mathrm{Zn}, \mathrm{V}, \mathrm{Ba}$ ) as described in Tresch et al. (2018b) (cf. Table 2).

\subsubsection{Garden land-use type features}

Six garden land-use type features expected to influence soil biodiversity and decomposition were assessed on at each litter bag site. Plant species richness ( $\mathrm{S}$ plants) was calculated as the total number of plant species per sampling site, using a floristic inventory of cultivated and spontaneously growing plants. The species list of the 600 plants and the identification methodology can be found in (Frey et al., 2018b). The amount of sun hours measured with a solar compass at maximum vegetation stage in July 2015 at $0.3 \mathrm{~m}$ height and the proportion of bare or impervious soil by taking orthogonal photographs taken at $3 \mathrm{~m}$ height and classified with digital image classification (ImageJ). Mean inclination of the sites (slope) was measured with a digital elevation meter. Each site was grouped into one of the three land-use types: grass, forbs or crops.

\subsubsection{Garden management and garden features}

Garden management was assessed by using a questionnaire with 26 questions (cf. Table A.6) about the physical (e.g. frequency of lawn cutting) and chemical (e.g. fertiliser) soil management practices. Questions were asked for each land-use type separately. A management intensity index was created similar to Smith et al. (2006) by summing up all management variables, which were ordered from low to high intensity on a five level Likert scale. The time since the last major change in the garden was defined as the garden age, while the garden types (allotment or home garden) were given by the sampling design.

\subsubsection{Urban intensity gradient}

We used urban warming as a surrogate of urbanisation intensity, because it is a direct effect of the density and amount of impermeable surfaces (Fig. B.7; Davidson and Janssens (2006)). Urban warming was defined as the deviation of mean night temperatures near the surface (ranging from 0 to $+6^{\circ} \mathrm{C}$ ) from a local climate model by Parlow et al. (2010). For group comparisons (Table 3, Table 6), urban warming was grouped into three classes: class 1 containing gardens with $0-1{ }^{\circ} \mathrm{C}$ mean night temperatures, class 2 with $2-3^{\circ} \mathrm{C}$ and class 3 with $4-5^{\circ} \mathrm{C}$.

\subsection{Data analysis}

\subsubsection{Litter decomposition model}

Direct effects on litter decomposition were analysed with a linear mixed effect model (LMEM), which was chosen due to the nested structure of the sampling sites within the gardens. The response variable (i.e. litter mass loss) was transformed $(\log (100-x+1))$ to approach independent and identically distributed residuals (Fig. B.2). Before model selection, Pearson correlation analysis (Dormann et al., 2013) and the variance inflation factor $(\mathrm{VIF}<10$; Borcard et al. (2011)) were used to reduce collinearity issues. We chose species richness $(S)$ and evenness ( $\left.E_{\text {Shannon }}\right)$ to represent taxonomic diversity since abundance $(\mathrm{N})$ was correlated with evenness $(\mathrm{r}<-0.6$; Fig. B.4). Subsequently, TED was selected to represent trait evenness and PSV the phylogenetic diversity, since all other indices were highly correlated ( $r>0.7$; Fig. B.5) with species diversity or evenness. Goodness of fit statistics for LMEM were the widely applicable information criterion (WAIC), which is a Bayesian version of the AIC (Watanabe, 2010) and variance explained (including random factor $R^{2}$ Conditional and for fixed effects $\mathrm{R}^{2}$ Marginal only; Nakagawa and Schielzeth, 2013). These statistics, suggested inclusion of garden type, MSIR, representing the microbial activity and urban warming, in the final litter decomposition model (delta WAIC $41 \pm 13$, delta $\mathrm{R}^{2}$ Marginal $0.22 \pm 0.05$ and delta $\mathrm{R}^{2}$ Conditional $0.32 \pm 0.08$; Table A.7). The final LMEM was analysed with a Bayesian approach including means and 95\% credible intervals of the Bayesian inference posterior distributions following Korner-Nievergelt et al. (2015).

\subsubsection{Multilevel structural equation model (SEM)}

Direct and indirect effects of soil characteristics, garden management, and the urban intensity gradient on litter decomposition were assessed using a multilevel SEM (Shipley, 2016) implemented in the 'piecewiseSEM' package (Lefcheck, 2016). Leaf $4 \mathrm{~mm}$ was used as a litter decomposition response, as it is better degradable than stem material and includes all soil fauna communities of this study. Composite models of the SEM were LMEM (Pinheiro et al., 2018) with garden ID (two sites nested within one garden) as random factor. Basis set construction (see R script in Appendix), goodness-of-fit tests and parameter estimations were conducted according to AICC and Fisher's C statistic ( $p>0.05$; Shipley, 2016). We checked for missing paths in the SEM with Shipley's d-separation test. Model assumption were tested (Fig. B.12) and potential spatial autocorrelation patterns in the response variables were calculated with Moran's I autocorrelation indices (Popescu et al., 2012) and the spatial structure in the model residuals (Fig. B.10) using semivariograms (Pebesma, 2004).

\subsubsection{NMDS ordination and PERMANOVA}

Litter residues after decomposition were analysed by a multivariate analysis of midDRIFTS measurements (Table 2) with a non-metric multidimensional scaling (NMDS) and a permutational multivariate analysis of variance (PERMANOVA) with a distance matrix (Gower index) using the 'vegan' package (Oksanen et al., 2016). For the PERMANOVA, we used only significant variables $(p \leq 0.05)$ from the multilevel SEM, and for the NMDS, only significant variables from the PERMANOVA were fitted (Fig. 5).

All statistical analyses were performed using R 3.4.2 (R Core Team, 2017), a script with $R$ codes used for the calculation of descriptive statistics, tables and diversity indices as well as the LMEM and SEM are provided in the Appendix. 
Table 2

Variables expected to directly or indirectly affect litter decomposition in urban gardens, including potential positive $\uparrow$ or negative $\downarrow$ effects on decomposition. Management questions used for the calculation of garden management variables can be found in Table A.9. Additional information about soil characteristics can be found in Tresch et al. (2018b) and about plant characteristics in Frey et al. (2018b).

\begin{tabular}{lll}
\hline Variables $\quad$ Expected effect $\quad$ Description \\
\hline
\end{tabular}

Direct/indirect environmental factors and management practices

\section{Plot scale}

Soil physical characteristics

$\mathrm{BD}\left[\mathrm{g} \mathrm{cm}^{-3}\right]$

Depth $[\mathrm{cm}]$

PR [MPa]

PV [\%]

SA [\%]

Soil texture (3) [\%]

WHC [\%]

\section{Soil chemical characteristics}

$\mathrm{pH}$

EC $\left[\mu \mathrm{S} \mathrm{cm}^{-1}\right]$

Nutrients (7) [ $\left.\mathrm{mg} \mathrm{kg}^{-1}\right]$

Soil biological characteristics Basal $\left[\mu \mathrm{g} \mathrm{CO}_{2}-\mathrm{Cg}^{-1} \mathrm{~h}^{-1}\right]$ Bacteria [gene copy numbers]

$\mathrm{C}_{\min }\left[\mu \mathrm{g} \mathrm{CO} \mathrm{CO}_{2}-\mathrm{C} \mathrm{kg}^{-1}\right]$

$\mathrm{N}_{\text {min }}\left[\mathrm{mg} \mathrm{kg}^{-1}\right]$

$\mathrm{C}_{\text {mic }}\left[\mathrm{mg} \mathrm{kg}^{-1}\right]$

$\mathrm{N}_{\text {mic }}\left[\mathrm{mg} \mathrm{kg}^{-1}\right]$

DOC [\%]

DON [\%]

SOC [\%]

TON [\%]

Soil heavy metals

Heavy metals (9) $\left[\mathrm{mg} \mathrm{kg}^{-1}\right] \quad \downarrow$

Land-use type characteristics

Bare soil [\%]

Impervious [\%]

Sun hours [h]

Slope [\%

$S$ plants

Land-use types

$\downarrow$

$\downarrow$

Garden management

Management index

Disturbance

Weeding

Pesticides

Removing leaves

Water

Fertiliser

\section{Garden features}

Garden age [a]

Garden type

City scale

Urban intensity gradient

Urban warming

Sealed area

Direct effects soil fauna

Taxonomic diversity

$\mathrm{N}$

$D_{\text {Shannon }}$

EShannon
Soil bulk density

Soil depth (up to max. $80 \mathrm{~cm}$ )

Mean penetration resistance

Soil pore space volume

Soil stable aggregates

Soil texture clay, silt, sand

Soil water holding capacity

Soil pH

Electrical conductivity

Nutrient contents of $\mathrm{P}$ (phosphorus), $\mathrm{K}$ (kalium), Mg (magnesium),

$\mathrm{Fe}$ (iron), $\mathrm{Cu}$ (copper), Mn (manganese), B (boron)

Basal soil respiration

Bacterial gene copy numbers of $16 \mathrm{~S}$ qPCR rRNA

Carbon mineralisation (4 weeks respiration measurement)

Nitrogen mineralisation

Microbial biomass carbon

Microbial biomass nitrogen

Dissolved organic carbon

Dissolved organic nitrogen

Soil organic carbon content

Total organic nitrogen content

$\mathrm{Sb}$ (antimony), As (arsenic), Co (cobalt), Cu (copper), $\mathrm{Pb}$ (lead), $\mathrm{Ni}$ (nickel), Zn (zinc), V (vanadium), Ba (barium)

Proportion of soil not covered with vegetation on plot level $\left(10 \mathrm{~m}^{2}\right)$ Proportion of sealed soils on plot level $\left(10 \mathrm{~m}^{2}\right)$

Solar hours (solar compass at maximum vegetation stage in July 2015)

Mean inclination measured with a digital elevation meter $(\mathrm{n}=10)$

Plant species richness identified at plot level $\left(10 \mathrm{~m}^{2}\right)$

Three main garden land-use types (grass, forbs, crops)

Management intensity index (sum of 26 management questions; Table A.6) Frequency of major soil disturbance (DiggingVeg, DiggingFlower, CareLawn) Frequency of removing weeds in the garden (Weeds)

Pesticides (PestLawn, PestFeg, PestFlower, PestTrees, WeedingHerbicide) Removing leaves in the garden (Leaves)

Frequency of irrigation (WaterLawn, WaterVeg, WaterFlower)

Applying fertiliser (FertGrass, FertCrops, FertForbs)

Time since last major change in the garden (e.g., exchange of soil)

Two main urban garden types (allotment and home gardens)

Deviation of local mean night temperatures $\left(0\right.$ to $\left.+6^{\circ} \mathrm{C}\right)$

Proportion of sealed area around each garden $(30,50,100,250,500$ m radius $)$

Soil fauna abundance

Soil fauna species richness

Shannon diversity index

Shannon evenness

(continued on next page) 
Table 2 (continued)

\begin{tabular}{lll}
\hline Variables & Expected effect & Description \\
\hline Functional diversity & & \\
TED & $\downarrow$ & Trait even distribution \\
FDis & $\uparrow$ & Functional dispersion index \\
TOP & $\uparrow$ & Trait onion peeling index \\
& & \\
Phylogenetic diversity & $\uparrow$ & \\
PD & $\downarrow$ & Phylogenetic diversity \\
PSE & $\uparrow$ & Phylogenetic species evenness \\
PSV & $\uparrow$ & Phylogenetic species variability \\
PSR & & Phylogenetic species richness \\
Microbial activity & $\uparrow$ & \\
MSIR & $\uparrow$ & Multiple substrate-induced respiration rate \\
\hline
\end{tabular}

\section{Results}

In the biodiversity assessment of urban gardens, we collected 39 collembola (13,694 individuals), 18 earthworm (3128 individuals), 16 isopod (59,650 individuals) and 47 gastropod (4535 individuals) species (Table A.5). Total soil fauna species richness was highest for forbs and lowest for crops and decreased with increasing urban warming class. Whereas soil fauna abundance was highest for grass, lowest for crops and increased with urban warming classes (Table 3). These results varied among the taxonomic groups, for instance - $\mathrm{S}_{\text {Gastropods }}$ increased while $\mathrm{S}_{\text {Earthworms }}, \mathrm{S}_{\text {Collembola }}, \mathrm{S}_{\text {Isopods }}$ decreased with urban warming classes (cf. Table A.4).

Mean mass loss of leaf litter ( $1 \mathrm{~mm}: 61.2 \pm 2.0 \%$; 4 mm: $79.6 \pm$ $2.2 \%$ ) was significantly higher (Table A.9; Fig. 2) compared to the more recalcitrant stems ( $1 \mathrm{~mm}: 40.1 \pm 1.0 \% ; 4 \mathrm{~mm}: 37.9 \pm 0.8 \%$ ). We observed a significant effect of the macrofauna community $(4 \mathrm{~mm}$ mesh size) for leaf litter compared to those with $1 \mathrm{~mm}$ mesh size that exclude soil macrofauna species. No mesh size effect was observed for the stems.

\subsection{Litter decomposition model}

Garden land-use types showed the largest effect in the LMEM (Table A.8) on litter decomposition, irrespective of litter type and mesh size (Fig. 3; Fig. B.8). Mean decomposition rates of grass sites (Leaf $4 \mathrm{~mm}: 90.5 \pm 1.8 \%$, Stem $4 \mathrm{~mm}: 42.8 \pm 0.9 \%$, Leaf $1 \mathrm{~mm}$ : $69.6 \pm 2.2 \%$, Stem $1 \mathrm{~mm}: 46.0 \pm 1.0 \%)$ were higher compared to forbs (Leaf $4 \mathrm{~mm}: 80.7 \pm 3.5 \%$, Stem $4 \mathrm{~mm}: 37.9 \pm 1.2 \%$, Leaf $1 \mathrm{~mm}$ :
$56.2 \pm 3.5 \%$, Stem $1 \mathrm{~mm}: 39.1 \pm 1.6 \%$ ) and crops (Leaf $4 \mathrm{~mm}$ : $61.8 \pm 5.6 \%$, Stem $4 \mathrm{~mm}: 30.5 \pm 1.9 \%$, Leaf $1 \mathrm{~mm}: 45.1 \pm 5.3 \%$, Stem $1 \mathrm{~mm}: 30.0 \pm 3.1 \%)$. Urban warming was positively related to higher decomposition rates irrespective to the litter type and mesh size. Soil fauna species richness (S) and microbial activity (MSIR) were positively related to mass loss of leaves in $4 \mathrm{~mm}$ and stems in $1 \mathrm{~mm}$ litter bags (Table A.8). None of the functional and phylogenetic diversity indices significantly explained decomposition in our study. Mean decomposition rates were influenced by garden management practices. For instance, major soil disturbance (i.e. digging) correlated with decreased decomposition rates in forbs irrespective of litter type and mesh size (Table A.9). The addition of compost led to increased leaf decomposition in $4 \mathrm{~mm}$ bags for grass sites and water application to increased decomposition of stems in $1 \mathrm{~mm}$ bags.

\subsection{Multilevel structural equation model}

The multilevel SEM (Fig. 4) was used to test both direct and indirect effects of environmental factors (Table 2) on the soil fauna community and on the ecosystem function litter decomposition. The SEM fit the criteria (Shipley, 2016) that there are no missing relationships among unconnected variables (AICc $=299.7$, Fisher's C $=124.2$, pvalue $=0.96$ ). Overall, $55 \%$ of the variation in leaf litter decomposition of the $4 \mathrm{~mm}$ litter bags has been explained in the multilevel SEM. Soil fauna species richness had a direct positive influence on decomposition and was positively affected by plant species richness in the gardens, but negatively by soil antimony $(\mathrm{Sb})$ content, explaining in total $39 \%$ of the variation in species richness (Table 4 ). Garden soils

Table 3

Descriptive statistics of biodiversity components. Soil fauna species richness (S) and abundance (N) are presented in Table A.4, and the species and trait list of soil fauna used for the calculation of the biodiversity components are shown in Table A.5. Presented values are mean values with standard errors. $D_{\text {Shannon }}$ : Shannon diversity index, Eshannon: Shannon evenness, FDis: Functional dispersion index, MSIR: Multi substrate-induced respiration rate, N: Abundance, PD: Phylogenetic diversity, PSE: Phylogenetic species evenness, PSR: Phylogenetic species richness, PSV: Phylogenetic species variability, S: Species richness, TED: Trait even distribution, TOP: Trait onion peeling index. All garden sites $\mathrm{n}=168$, crops $n=46$, forbs $n=52$, grass $n=70$, allotment $n=82$, home $n=86$, Urban warming class $1 n=34$, Urban warming class $2 n=114$, Urban warming class $3 n=20$.

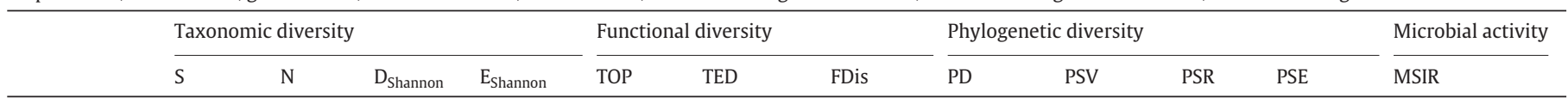

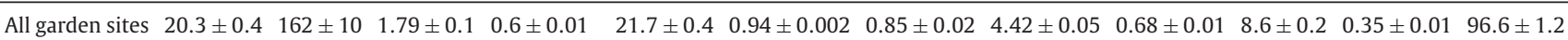

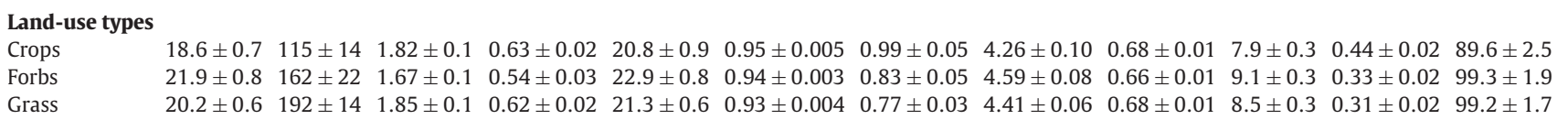

Garden types

$\begin{array}{lllllllllllll}\text { Allotment } & 20.7 \pm 0.6 & 147 \pm 13 & 1.88 \pm 0.1 & 0.63 \pm 0.02 & 22.1 \pm 0.7 & 0.94 \pm 0.004 & 0.9 \pm 0.04 & 4.47 \pm 0.07 & 0.68 \pm 0.01 & 8.8 \pm 0.3 & 0.39 \pm 0.02 & 91.9 \pm 1.8\end{array}$

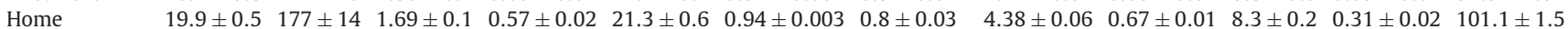

\section{Urban warming}

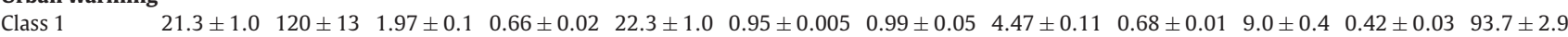

$\begin{array}{lllllllllllllllllllll}\text { Class } 2 & 20.3 \pm 0.5 & 154 \pm 10 & 1.86 \pm 0.1 & 0.62 \pm 0.01 & 21.8 \pm 0.5 & 0.94 \pm 0.003 & 0.86 \pm 0.03 & 4.43 \pm 0.05 & 0.68 \pm 0.01 & 8.6 \pm 0.2 & 0.36 \pm 0.01 & 97.2 \pm 1.4\end{array}$

Class 3

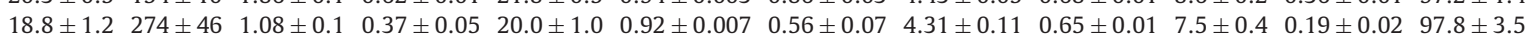




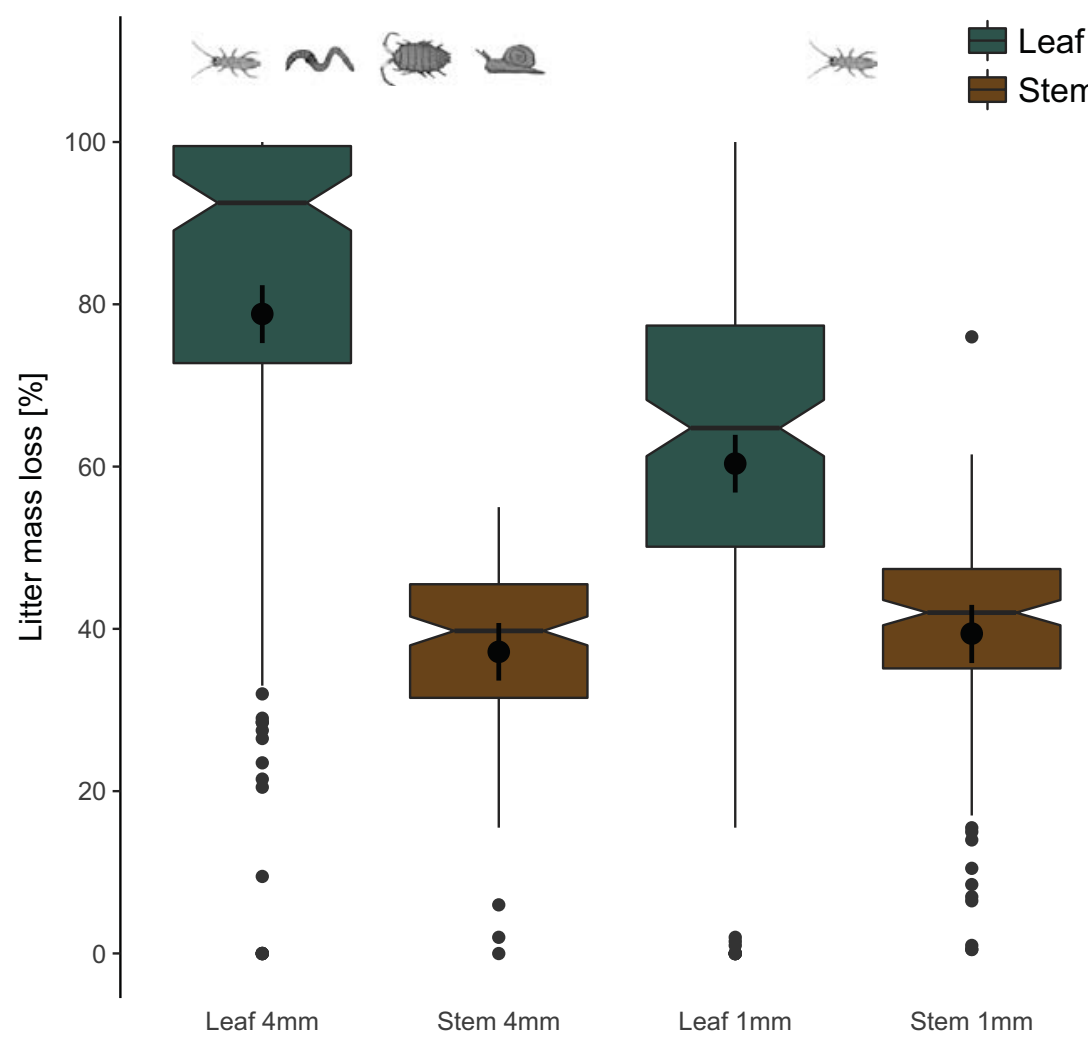

Fig. 2. Litter mass loss by litter type (leaf and stem of Zea mays L.) and mesh size ( 1 \& $4 \mathrm{~mm}$ ). Soil fauna drawings indicate sampled soil mesofauna (collembola) and macrofauna (earthworms, isopods, gastropods). Bold points are mean values of the simulated Bayesian inference posterior distribution with the 95\% credible intervals as lines (cf. Table A.9). Colours correspond to litter types.

with higher contents of microbial biomass $\left(C_{\text {mic }}\right)$ and bacteria also had elevated microbial activity (MSIR) that positively affected litter decomposition. Moreover, plant species richness covaried positively with microbial activity, explaining $41 \%$ of the variation.

\subsection{Effects on litter residue quality}

Several variables had a significant effect on the quality of litter residues after decomposition (Table 5). Land-use types showed the greatest effect on the composition of litter resides of functional organic compounds (PERMANOVA; $\mathrm{R}^{2}=0.08 ; \mathrm{p} \leq 0.001$ ). In the NMDS ordination (Fig. 5 ) crop sites were associated with more labile litter quality compounds, while grass and forb sites were associated with more stable compounds. Soil fauna species richness (S; PERMANOVA; $R^{2}=0.02 ; p=0.01$ ), was positively associated with stable organic compounds. Furthermore, the management variable leaf removal (PERMANOVA; $\mathrm{R}^{2}=0.03 ; \mathrm{p} \leq 0.001$ ) as well as total organic nitrogen (PERMANOVA; TON; $\mathrm{R}^{2}=0.02 ; \mathrm{p}=0.01$ ) contributed to the separation of the litter residue quality after decomposition for the leaf $4 \mathrm{~mm}$ litter bags.

\section{Discussion}

One of the main challenges of sustainable urban development is reducing the rate of urban soil sealing (Artmann, 2016), which is steadily increasing at the expense of highly contested green spaces such as gardens (Tappert et al., 2018). In European cities, green spaces are declining regardless of whether the urban population is shrinking or growing (Kabisch and Haase, 2013). In this context, we aimed to contribute to the discussion on the importance of urban gardens for the biodiversity of a city and to investigate which and how biotic and abiotic factors drive BEF relationships. In the present study, we used urban gardens as model system to explore above and belowground BEF relationships in a human dominated environment and investigated direct and indirect effects on soil organisms and litter decomposition at different spatial scales. Our results showed that decomposition was highest when soil macrofauna was involved. This is in line with the results that soil fauna diversity increases decomposition across biomes found by the study of Handa et al. (2014). Overall, our results showed that the way gardeners manage land-use types and how the surrounding urban matrix is composed, can have an important effect on litter decomposition.

\subsection{Soil fauna drives litter decomposition also in human dominated ecosystems}

Environmental conditions such as climate or soil characteristics together with litter quality, are the main influencing factors of decomposition across biomes, with the decomposer community contributing substantially (García-Palacios et al., 2016b). In this study, we used four major taxonomic soil fauna groups and calculated indices of taxonomic, functional and phylogenetic biodiversity representing different facets of soil fauna biodiversity to assess direct effects on litter decomposition. Regarding the litter bags including all soil fauna, we observed higher decomposition rates for the better decomposable leaf litter type. Looking at macrofauna only, we observed generally higher litter decomposition rates for the better decomposable leaf litter type. This could be explained partially by the food preference of macrofauna, which will first feed on the most palatable available litter, and only consume litter of low nutritional value later when other resources are not available and once microorganisms have increased its palatability through their presence and the degradation of recalcitrant compounds such as lignin (Vos et al., 2011). In our study, taxonomic diversity of soil fauna species was the 


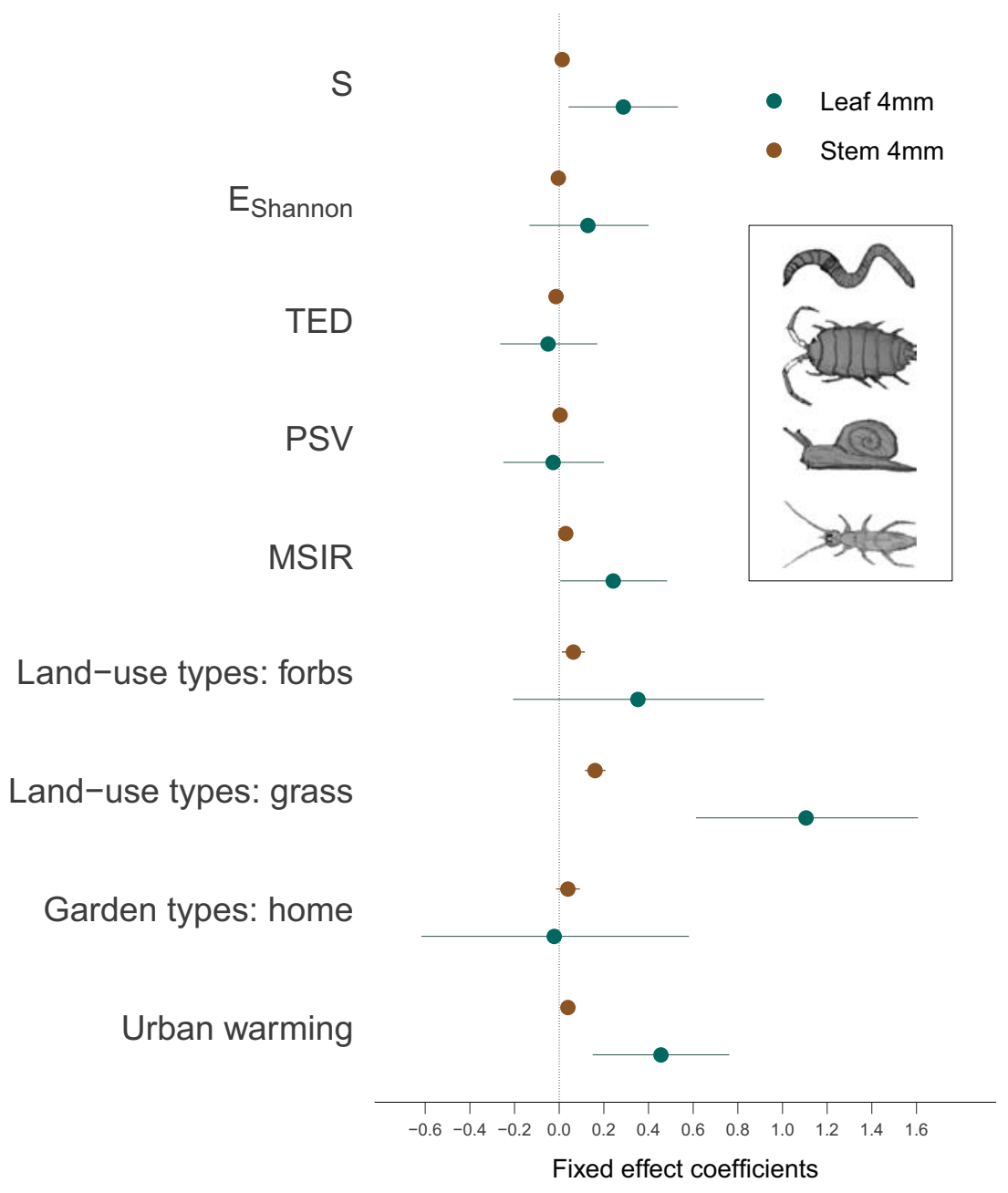

Fig. 3. Litter decomposition model fixed effect plots with $4 \mathrm{~mm}$ mesh size (see Fig. B.8 for LMEM with 1 mm mesh size). Points indicate mean values of simulated Bayesian inference posterior distribution with the $95 \%$ credible intervals as lines. Colours correspond to litter types.

driving diversity aspect affecting litter decomposition on both the LMEM and the SEM (Figs. 3, 4). In relation the mass-ratio hypothesis, claiming that ecological processes are driven by the traits of the most abundant species within the community (Grime, 1998), we tested the effect of soil fauna abundance on litter decomposition (Table A11.), but no significant effects were detected and the model goodness-of-fit tests decreased. Moreover, functional and phylogenetic diversity did not explain litter mass loss, although it has been shown that species identity is important for the decomposition process, as functionally different groups of macrofauna can interact positively (Heemsbergen, 2004). Nevertheless, functional diversity is usually highly correlated with taxonomic diversity in most BEF investigations (Gessner et al., 2010), but maybe not in very complex soil fauna communities. In our study, we used four taxonomic groups of soil fauna, which occur ubiquitously and are phylogenetically distant from each other. This may have resulted in similar phylogenetic and functional variation among soil fauna communities, because differences in species functional traits or phylogenetic indices were highest between the investigated taxonomic groups.

4.2. Garden land-use and management intensity affect decomposition mediated by soil fauna

Garden land-use management practices, such as soil tillage or planting vegetables are important factors of soil biodiversity in cities (Beninde et al., 2015), including less mobile soil invertebrates (Braaker et al., 2014). Likewise, in our study, management of landuse types was also the dominant factor for litter decomposition: regardless of litter type or mesh size. For instance, $83 \%$ of all 85 gardeners used compost for their crops. The use of compost has been reported as a moderate and relatively cost-effective management practice against urban soil problems such as soil compaction, lack of organic matter, or heavy metal pollution (Lusk and Toor, 2018). An adequate addition of good quality compost has been shown to have positive effects on several soil properties such as bulk density, porosity, aggregate stability, water holding capacity or infiltration (Cogger, 2005). In our study, adding compost had a positive effect on decomposition rates, while major soil disturbance, such as digging or loosening the soil, reduced decomposition rates across leaf litter type and mesh size. The use of pesticides was not a significant factor affecting decomposition (Table A.9). This could be influenced by several factors, such as the types and amounts of pesticides used, which were not investigated here. Nevertheless, a study of the effects of pesticides on soil fauna diversity, soil quality or food quality would be of great interest, as many gardeners are not aware of the negative consequences on soil and its diversity (Zaller, 2018).

In addition to management practices, soil characteristics may also contribute to the effect of aboveground biota on decomposition processes in urban gardens. An example is a reciprocal litter 


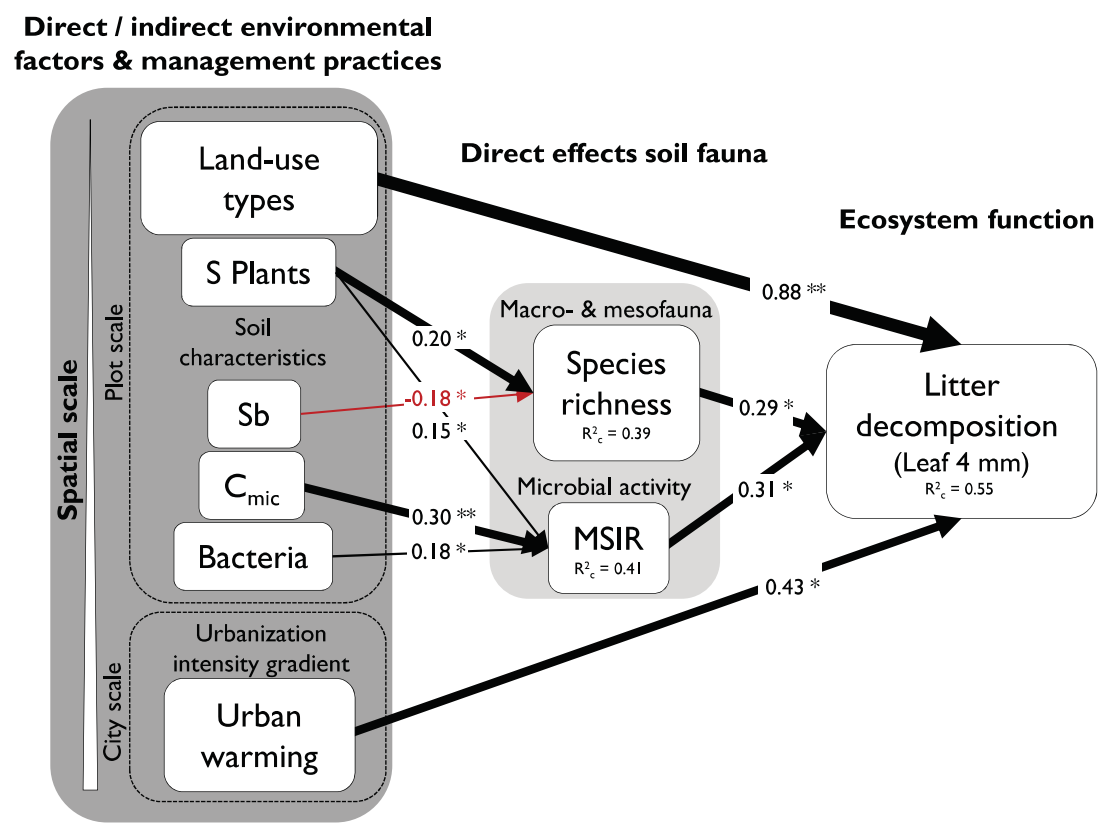

Fig. 4. Final SEM of direct and indirect effects of land-use features, soil characteristics and urbanisation intensity and direct effects of soil fauna on leaf litter decomposition. Arrows represent unidirectional relationships among variables. Black arrows denote positive and red arrows negative relationships. Variables not affecting decomposition significantly $(\mathrm{p}>0.05)$ are not included in this graphical representation (see Table 4). The thickness of paths has been scaled based on the magnitude of the standardised regression coefficient, given in the associated box. Conditional $\mathrm{R}^{2}$, based on the variance of both the fixed and random effects, for component models are given in the boxes of response variables. $\mathrm{C}_{\mathrm{mic}}$ : Microbial biomass carbon, MSIR: Multiple substrate-induced respiration of microorganisms, S plants: Plant species richness, Sb: Antimony content.

decomposition experiment in the city of Lahti, Finland, in which soil type was one of the main factors affecting decomposition (Vauramo and Setälä, 2011). In our study, we observed that several soil properties affected the soil fauna community. Soils with higher amounts of microbial biomass and bacteria had a higher microbial activity (Fig. 4), thus indirectly increased litter decomposition (Table 4). Despite the importance of fungi in decomposition (e.g. Seastedt, 1984; Kabuyah et al., 2012), we only found effects of bacteria on microbial activity (Fig. B.13, Table A.10) increasing indirectly decomposition of the less recalcitrant litter material (Table A.1). In fact, similar results have been found by Girvan et al. (2004), who showed that soil management practices such as fertilisation or the use of pesticides affected bacterial but not fungal communities. Furthermore, the soil heavy metal antimony content showed a negative effect on soil fauna species richness and plant diversity (Fig. B.11) had a positive effect on soil fauna species richness and microbial activity. This is in line with the study by Ebeling et al. (2018), in which higher plant species richness supported more diverse and complex arthropod communities: thus affecting ecosystem services in grassland ecosystems. Therefore, we can conclude that garden management, for instance how many plant species are planted, not only influences soil properties, but also indirectly influences litter decomposition via the change of the soil fauna communities.

\subsection{Effects on litter residue quality}

Litter residues were analysed to show effects of biotic or abiotic factors on the litter quality, complementary to the litter mass loss analysis. MidDRIFTS peak measurements were selected to represent contrasting functional organic compounds of the remaining litter after decomposition (Table 1). We showed that soil fauna not only had a significant positive effect on litter decomposition but also determine litter residue quality. Sites with higher soil fauna species richness had more stable organic compounds (Fig. 5), while crop sites had more labile compounds left after the assessed decomposition period. Thus, a changed soil fauna community composition not only affected the mass loss but also the consumption of different organic compounds of the leaf litter. Interestingly, the management practice 'leaf removal' resulted in a distinct grouping of sites regarding the litter residue quality. This indicates that at sites, where leaves were removed in winter, soil fauna were either less abundant because of restricted food resources, had a different community structure, or preferred the organic material of the litter bags.

\subsection{Effects of garden land-use type and urban warming on litter decomposition}

We hypothesised that garden land-use type and garden scale features will have a larger effect on soil biodiversity and litter decomposition than city scale factors. Our results highlighted an influence of garden land-use type features and soil characteristics on soil fauna and decomposition. Surprisingly, urban warming strongly positively affected litter decomposition and also shaped the soil fauna community (Table 4). This demonstrated that soil invertebrates are also influenced by large scale urban intensity gradients, similarly to previous findings on mobile species, such as bees (Pardee and Philpott, 2014). In this study, we found decreasing species richness but increasing abundance of soil fauna species across taxa, mainly because of the more abundant isopods in more urbanised gardens. Although most taxonomic groups of urban fauna occur at higher densities in rural environments than in non-rural ones, few species can be attributed as urban exploiters or even urban adapters (Evans, 2010). This pattern of population density depends on the species identity. For instance, crustacea such as isopods are dependent on the availability of calcium, as they frequently replace their cuticle (Fabritius and Ziegler, 2003), but also shelled gastropods rely on the calcium levels (Charrier et al., 2013). Carbonate in soils lead to moderate alkaline $\mathrm{pH}$ values, as found in this study with a mean $\mathrm{pH}$ value of $7.3 \pm 0.02$. The $\mathrm{pH}$ is expected to increase with urbanisation, due to calcium-rich materials used for construction (Kida and Kawahigashi, 2015), but also due to precipitation depositions caused by anthropogenic emissions (Blume et al., 2016). In our study soil pH 
Table 4

Multilevel SEM of litter decomposition (leaf $4 \mathrm{~mm}$ litter bags) investigating environmental factors on the soil fauna community and soil function decomposition (AICc $=299.7$, Fisher's $C=124.2$, p-value $=0.96$ ). Marginal $\mathrm{R}^{2}$ based on fixed effects and conditional $\mathrm{R}^{2}$ based on fixed and random effects. Significant paths are highlighted in bold. BD: Soil bulk density, $\mathrm{C}_{\text {mic }}$ : Microbial biomass carbon, $\mathrm{E}_{\text {Shannon }}$ : Shannon evenness, MSIR: Multiple substrate-induced respiration of microorganisms, $\mathrm{N}_{\min }$ : Nitrogen mineralisation, PSV: Phylogenetic species variability, S: Soil fauna species richness, Sb: Antimony content, TED: Trait even distribution, TON: Total organic nitrogen, WHC: Water holding capacity.

\begin{tabular}{|c|c|c|c|c|c|c|}
\hline Response & $\mathrm{R}_{\text {conditional }}^{2}$ & $\mathrm{R}_{\text {marginal }}^{2}$ & Predictor & Estimate & $\mathrm{p}$ & \\
\hline \multirow[t]{9}{*}{ Leaf $4 \mathrm{~mm}$} & 0.55 & 0.24 & Land-use types: grass & $0.88 \pm 0.3$ & 0.002 & $* *$ \\
\hline & & & Urban warming & $0.43 \pm 0.2$ & 0.01 & $*$ \\
\hline & & & MSIR & $0.31 \pm 0.1$ & 0.02 & $*$ \\
\hline & & & $\mathbf{S}$ & $0.29 \pm 0.1$ & 0.03 & * \\
\hline & & & $\mathrm{E}_{\text {Shannon }}$ & $0.14 \pm 0.1$ & 0.35 & \\
\hline & & & Land-use types: forbs & $0.22 \pm 0.3$ & 0.46 & \\
\hline & & & TED & $-0.07 \pm 0.1$ & 0.57 & \\
\hline & & & PSV & $-0.03 \pm 0.1$ & 0.79 & \\
\hline & & & Garden types: home & $0.05 \pm 0.3$ & 0.89 & \\
\hline \multirow[t]{8}{*}{ MSIR } & 0.41 & 0.39 & $\mathrm{C}_{\mathrm{mic}}$ & $0.30 \pm 0.09$ & 0.002 & $* *$ \\
\hline & & & Bacteria & $0.18 \pm 0.07$ & 0.02 & $*$ \\
\hline & & & S plants & $0.15 \pm 0.07$ & 0.04 & $*$ \\
\hline & & & Bare soil & $-0.12 \pm 0.08$ & 0.12 & \\
\hline & & & Sun hours & $-0.11 \pm 0.07$ & 0.14 & \\
\hline & & & WHC & $0.12 \pm 0.08$ & 0.14 & \\
\hline & & & $\mathrm{BD}$ & $-0.11 \pm 0.09$ & 0.21 & \\
\hline & & & Management index & $-0.06 \pm 0.07$ & 0.40 & \\
\hline \multirow[t]{6}{*}{ S } & 0.39 & 0.19 & S plants & $0.20 \pm 0.08$ & 0.02 & * \\
\hline & & & Sb & $-0.18 \pm 0.08$ & 0.03 & $*$ \\
\hline & & & Bare soil & $-0.15 \pm 0.08$ & 0.07 & \\
\hline & & & $\mathrm{N}_{\min }$ & $0.14 \pm 0.08$ & 0.08 & \\
\hline & & & MSIR & $0.14 \pm 0.08$ & 0.09 & \\
\hline & & & Remove leaves & $-0.12 \pm 0.09$ & 0.17 & \\
\hline \multirow[t]{6}{*}{$\mathrm{E}_{\text {Shannon }}$} & 0.54 & 0.36 & Urban warming & $-0.46 \pm 0.08$ & $<0.001$ & $* * *$ \\
\hline & & & MSIR & $-0.19 \pm 0.07$ & 0.008 & $* *$ \\
\hline & & & PSV & $0.16 \pm 0.07$ & 0.02 & $*$ \\
\hline & & & $\mathbf{S}$ & $0.16 \pm 0.07$ & 0.02 & $*$ \\
\hline & & & TED & $-0.14 \pm 0.07$ & 0.04 & * \\
\hline & & & Management index & $0.09 \pm 0.07$ & 0.21 & \\
\hline \multirow[t]{2}{*}{ PSV } & 0.29 & 0.10 & Urban warming & $-0.24 \pm 0.09$ & 0.007 & $* *$ \\
\hline & & & Fertiliser & $0.21 \pm 0.09$ & 0.02 & $*$ \\
\hline \multirow[t]{5}{*}{ TED } & 0.22 & 0.07 & Land-use types: grass & $-0.38 \pm 0.2$ & 0.06 & \\
\hline & & & $\mathrm{S}$ & $0.11 \pm 0.09$ & 0.20 & \\
\hline & & & TON & $0.10 \pm 0.09$ & 0.24 & \\
\hline & & & Urban warming & $-0.10 \pm 0.09$ & 0.25 & \\
\hline & & & Land-use types: forbs & $-0.01 \pm 0.20$ & 0.98 & \\
\hline
\end{tabular}

did not increase with urbanisation (Fig. B.14, Table A.10). This can be explained by the overlying effect of garden management practices (e.g. liming), leading to increased pH values in annual vegetated sites. However, it is difficult to quantify the pure effect of urban intensity on soil fauna due to the complex structure and functioning of urban ecosystems (McDonnell et al., 1997) and because other factors, such as management practices or pollution can also influence soil functions such as decomposition (Pouyat et al., 1997).

Studies investigating the effect of urbanisation on litter decomposition (Table 6) revealed mixed effects with six out of twelve studies indicating a positive effect on decomposition with increasing urbanisation, while two showed no trends and four showed negative effects. This uncertainty associated with the effect of urbanisation on decomposition is likely due to the large variety of anthropogenic disturbances associated with different definitions of urbanisation and the strong local impact of management (Enloe et al., 2015). The quality of urban litter can be reduced by environmental pollutants affecting plant growth and leaf senescence (Carreiro et al., 1999). Alternatively, urban warming may accelerate metabolic processes and thus decomposition rates (Pouyat and Carreiro, 2003). Indeed, we found a positive association between urban warming and microbial activity (Table 3; Table A.9).

However, a comparison of decomposition studies across cities should be done with caution due to differences of the abiotic environment, experimental design or also in the site conditions such as contrasting soil types (Berg and McClaugherty, 2003). Almost all investigations shown in Table 6 have been done on urban forests with litter bags of different tree species including mixtures of them. The main reason for a positive effect of urbanisation on decomposition were higher temperatures either in soil (Pouyat and Carreiro, 2003; Pouyat et al., 1997) or air at urban sites (Nikula et al., 2010). Studies with negative effects of urbanisation on decomposition were mainly driven by heavy metals (Cotrufo et al., 1995; Inman and Parker, 1978), as they are known to reduce decomposer activity (Bååth, 1989). Moreover, urban soils in Kiel and Rostock, Germany, were found to have higher aromatic compounds which reduced decomposition but increased SOC with urbanisation (Beyer et al., 2001). Finally, non-native plants in urban forests can increase decomposition rates if they replace native plants which decompose more slowly (Ehrenfeld, 2003). The positive effects of urban warming on aboveground litter decomposition confirmed the results of a former study with tea bags as a measure of belowground decomposition (Tresch et al., 2018a). Taken together, our results suggest that the increased decomposition with urbanisation intensity can be explained by combined effects of higher microbial activity, more soil moisture through watering or ecological gardening activities (e.g. cover crops, mulch or compost), and a changed soil fauna composition, such as more gastropod species and higher abundance of isopods (Table A.4).

\subsection{Study limitations and perspectives}

Our study design maximised the numbers of sites under actual garden management in one city with the aim of investigating direct 


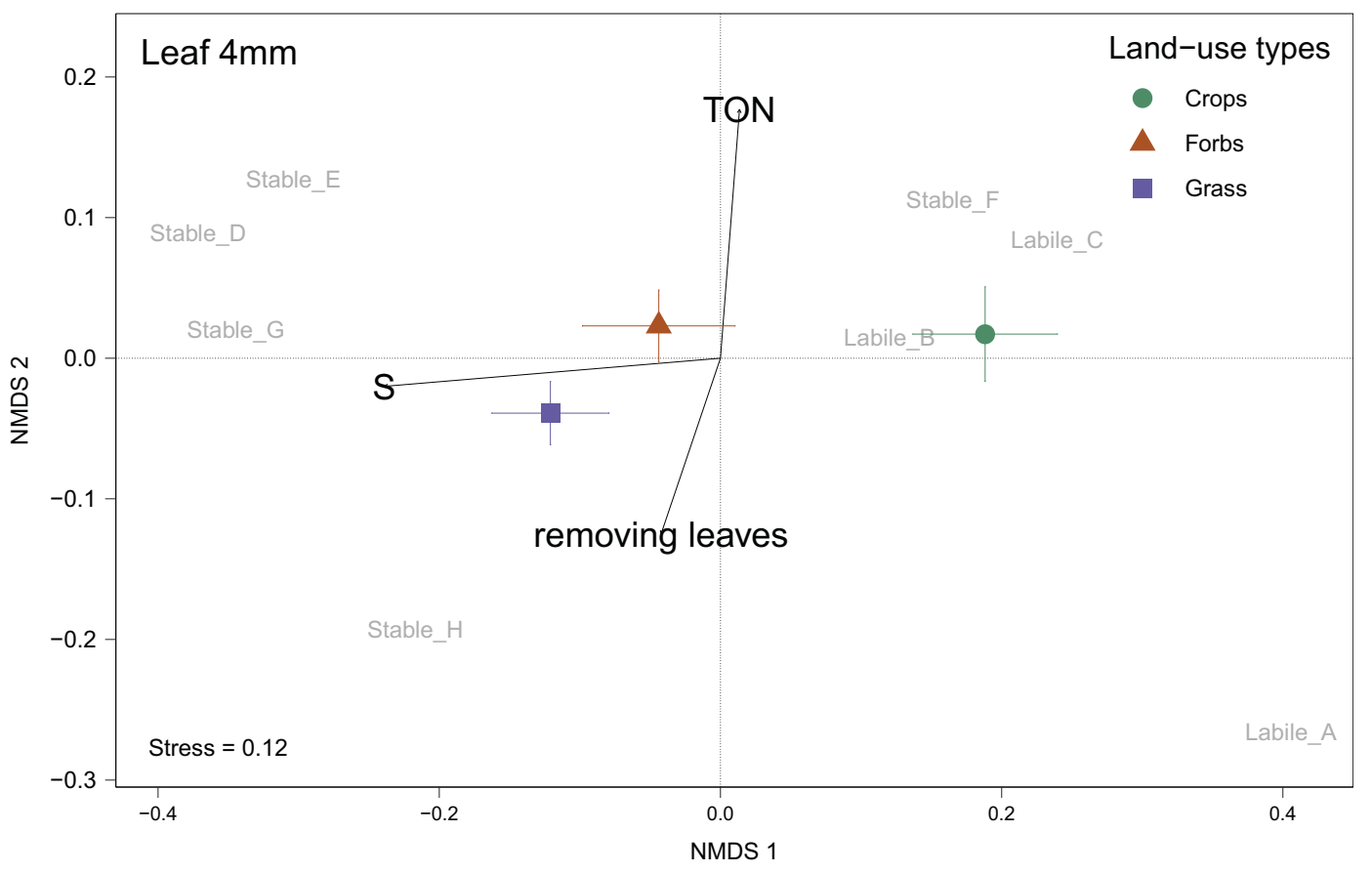

Fig. 5. Multivariate NMDS ordination of functional organic compounds of litter residues after decomposition (cf. Table 1). Leaf litter (4 mm mesh size) quality compounds are printed in grey. Variables significantly affecting the litter quality (cf. Table 5) are fitted on the ordination (arrows). Symbols and colours correspond to the garden land-use types ( crops $n=23$, forbs $n=27$, grass $n=26$ ). Bold points correspond to mean values per land-use type and lines indicate standard errors. S: Soil fauna species richness, TON: Total organic nitrogen.

and indirect effects of biotic and abiotic factors on litter decomposition at different spatial scales, as suggested by Bradford et al. (2016). On the one hand, the use of two litter types, one easily decomposable (leaf parts of Zea mays leaves) and one more difficult to decompose (stem parts of Zea mays leaves) allowed for a standardised and constant litter quality (Pouyat et al., 1997). On the other hand, the effect of multiple litter types on decomposition (e.g. Hättenschwiler and Gasser, 2005) could have contributed to a more general picture of litter decomposition since litter mixtures are more realistic representations of the decomposition process. Further, litter mixing can also influence decomposer organisms with complex interactions and regulate decomposition (Hättenschwiler and Gasser, 2005). Our assumption that litter bags with a mesh size of $1 \mathrm{~mm}$ are sufficient to exclude smaller macrofauna might not have been optimal, since Pouyat and Carreiro (2003) found that juvenile earthworms contributed significantly to leaf decomposition in litter bags with $1.7 \mathrm{~mm}$ mesh size. Regardless of the mesh size, juvenile species are often a problem in decomposition studies since they can hardly be determined to the species level. In addition, other soil fauna taxa affecting decomposition directly such as mites

\section{Table 5}

Multivariate analysis (PERMANOVA) of functional organic compounds of litter residues. Leaf litter (4 mm mesh size) quality compounds $(n=76)$ were used in a Gower distance matrix and significant variables from the multilevel SEM as predictor variables. Significant variables affecting the litter quality are bold printed. BD: Soil bulk density, $\mathrm{C}_{\text {mic }}$ : Microbial biomass carbon, $E_{\text {Shannon }}$ : Shannon evenness, MSIR: Multiple substrate-induced respiration of microorganisms, $\mathrm{N}_{\min }$ : Nitrogen mineralisation, $\mathrm{S}$ : Soil fauna species richness, Sb: Antimony content, TED: Trait even distribution, TON: Total organic nitrogen, WHC: Water holding capacity.

\begin{tabular}{|c|c|c|c|c|c|c|}
\hline Leaf $4 \mathrm{~mm}$ & & Df & F Model & $\mathrm{R}^{2}$ & $\mathrm{P}$ & \\
\hline \multirow[t]{3}{*}{ Soil fauna } & $\mathbf{S}$ & 1 & 1.7 & 0.02 & 0.01 & $* *$ \\
\hline & $\mathrm{E}_{\text {Shannon }}$ & 1 & 2.8 & 0.03 & 0.1 & \\
\hline & MSIR & 1 & 0.5 & 0.01 & 0.7 & \\
\hline \multirow[t]{7}{*}{ Soil characteristics } & TON & 1 & 1.6 & 0.02 & 0.01 & $*$ \\
\hline & WHC & 1 & 1.2 & 0.01 & 0.1 & \\
\hline & $\mathrm{Sb}$ & 1 & 1.1 & 0.01 & 0.2 & \\
\hline & $\mathrm{N}_{\min }$ & 1 & 1.3 & 0.02 & 0.7 & \\
\hline & $\mathrm{C}_{\text {mic }}$ & 1 & 0.8 & 0.01 & 0.1 & \\
\hline & $\mathrm{BD}$ & 1 & 0.7 & 0.01 & 0.2 & \\
\hline & Bacteria & 1 & 0.7 & 0.01 & 0.1 & \\
\hline \multirow[t]{4}{*}{ Plot scale } & Land-use types & 2 & 3.4 & 0.08 & $<0.001$ & $* * *$ \\
\hline & S plants & 1 & 0.6 & 0.01 & 0.6 & \\
\hline & Bare soil & 1 & 2.3 & 0.03 & 0.1 & \\
\hline & Sun hours & 1 & 0.5 & 0.01 & 0.7 & \\
\hline \multirow[t]{4}{*}{ Garden scale } & Remove leaves & 1 & 2.8 & 0.03 & $<0.001$ & $* *$ \\
\hline & Management index & 1 & 1.2 & 0.01 & 0.3 & \\
\hline & Fertiliser & 1 & 0.1 & 0.01 & 0.7 & \\
\hline & Garden types & 1 & 0.2 & 0.01 & 0.6 & \\
\hline \multirow[t]{2}{*}{ City scale } & Urban warming & 1 & 1.5 & 0.02 & 0.3 & \\
\hline & Residuals & 55 & & 0.66 & & \\
\hline
\end{tabular}


(Siepel and Maaskamp, 1994) or indirectly such as nematodes (García-Palacios et al., 2017) could have impacted leaf litter decomposition. Future studies should consider the variance of functional and phylogenetic indices within taxonomic groups and select traits based on their sensitivity to the focal environmental gradient and known effect to the target ecosystem function. Although body size and vertical stratification are reasonably connected with decomposition rates (Bardgett and Wardle, 2010; Briones, 2014), other traits related to the feeding habits of soil fauna species or habitat preferences would have been of great interest for their effects on decomposition. However, such traits are still missing for many meso- but also macrofauna species.

\section{Conclusion}

There is great private and public interest in how urban gardens enhance urban biodiversity in cities and how different management strategies are modifying this relationship (Ossola et al., 2018), for they deliver a range of ecosystem services to urban residents (Goddard et al., 2010). Our city-wide litter decomposition experiment revealed the importance of the interactions between the management of land-use types, urbanisation intensity and soil fauna dynamics. With a multilevel SEM, we highlighted direct and indirect effects of soil fauna, land-use, and soil characteristics on litter decomposition. For example, we showed that plant species richness indirectly influenced litter decomposition through increasing soil fauna species richness and microbial activity. This demonstrates for the first time that belowground BEF relationships in urban gardens are influenced by management and urbanisation intensity gradients. With this multi-indicator evaluation at different spatial scales, we emphasised the importance of both local and city scale factors on litter decomposition. The multivariate analysis of litter residue quality confirmed the importance of soil fauna species richness and landuse type management on litter decomposition and was therefore useful to go beyond litter mass loss to better understand decomposition processes. Future experiments on trait based BEF relationship in urban ecosystems are needed (Schwarz et al., 2017) to improve our mechanistic understanding about management impacts on urban green spaces, since robust knowledge about urban BEF relationships is essential to improve current and future practices in urban planning and management.

\section{Acknowledgments}

This study is part of an interdisciplinary project that focuses on biodiversity, soil quality, ecosystem services and human well-being of urban gardens (www.bettergardens.ch). It was supported by the Swiss National Science Foundation in frame of the Sinergia program (Grant no. CRSII1_154416). Further, we would like to thank the coordinator of the project BetterGardens Dr. Robert Home for his support and corrections. We are grateful for the help in the lab by Adolphe Munyangabe, Anton Kuhn, Lena Fischer (earthworms), Reto Henzmann (soil samples, earthworms), Bernhard Stehle (earthworms and microbial measurements), Dr. Lukas Pfiffner (earthworm identification), Selina Gugelmann (gastropod identification), Dr. Daniel Haefelfinger (litter decomposition), Dr. Scott Demian (midDRIFTS analysis) and Giulia Benazzi for their extraordinary support and help in the field or laboratory. Special thanks to Dr. Simone Fontana for providing the R-codes for TOP \& TED calculations as well as to Dr. Jörg Salamon (collembola identification) and Ferenc Visilics (isopod identification). We acknowledge in particular the participation of the 85 gardeners, who provided access and let us dig and sample soils in their gardens. 


\section{Appendix A. Supplementary data}

Supplementary data to this article can be found online at https:// doi.org/10.1016/j.scitotenv.2018.12.235.

\section{References}

Allan, E. Weisser, WW Fischer, M., Schulze, E-D, Weigelt, A, Roscher, C., Baade, J., Barnard, R.L., Beßler, H., Buchmann, N., Ebeling, A., Eisenhauer, N., Engels, C., Fergus, A.J.F., Gleixner, G., Gubsch, M., Halle, S., Klein, A.M., Kertscher, I., Kuu, A., Lange, M., Le Roux, X., Meyer, S.T., Migunova, V.D., Milcu, A., Niklaus, P.A., Oelmann, Y., Pašalić, E., Petermann, J.S., Poly, F., Rottstock, T., Sabais, A.C.W., Scherber, C., Scherer-Lorenzen, M., Scheu, S., Steinbeiss, S., Schwichtenberg, G. Temperton, V., Tscharntke, T., Voigt, W., Wilcke, W., Wirth, C., Schmid, B., 2013, sep. A comparison of the strength of biodiversity effects across multiple functions. Oecologia 173 (1), 223-237. https://doi.org/10.1007/s00442-012-2589-0.

Angold, P., Sadler, J., Hill, M., Pullin, A., Rushton, S., Austin, K., Small, E., Wood, B. Wadsworth, R., Sanderson, R., Thompson, K., 2006. Biodiversity in urban habitat patches. Sci. Total Environ. 360 (1-3), 196-204.

Aronson, M.F.J., Nilon, C.H., Lepczyk, C.A., Parker, T.S., Warren, P.S., Cilliers, S.S., Goddard, M.A., Hahs, A.K., Herzog, C., Katti, M., La Sorte, F.A., Williams, N.S.G., Zipperer, W., 2016, nov. Hierarchical filters determine community assembly of urban species pools. Ecology 97 (11), 2952-2963.

Artmann, M., 2016, jul. Urban gray vs. urban green vs. soil protection - development of a systemic solution to soil sealing management on the example of Germany. Environ. Impact Assess. Rev. 59, 27-42.

Bååth, E., 1989, oct. Effects of heavy metals in soil on microbial processes and populations (a review). Water Air Soil Pollut. 47 (3-4), 335-379.

Bardgett, R.D., Wardle, D.A., 2010. Aboveground-Belowground Linkages: Biotic Interactions, Ecosystem Processes, and Global Change. Oxford University Press.

Bartlett, M.D., Briones, M.J.I., Neilson, R., Schmidt, O., Spurgeon, D., Creamer, R.E., 2010 A critical review of current methods in earthworm ecology: from individuals to populations. Eur. J. Soil Biol. 46 (2), 67-73.

Bell, S., Fox-Kämper, R., Keshavarz, N., Benson, M., Caputo, S., Noori, S., Voigt, A., 2016. Urban Allotment Gardens in Europe. Routledge.

Beninde, J., Veith, M., Hochkirch, A., 2015, jun. Biodiversity in cities needs space: a meta-analysis of factors determining intra-urban biodiversity variation. Ecol. Lett. 18 (6), 581-592.

Benton, T.G., Vickery, J.A., Wilson, J.D., 2003. Farmland biodiversity: is habitat heterogeneity the key? Trends Ecol. Evol. 18 (4), 182-188.

Berg, B., McClaugherty, C., 2003. Plant Litter. Springer Berlin Heidelberg, Berlin, Heidelberg.

Beyer, L., Kahle, P., Kretschmer, H., Wu, Q., 2001. Soil organic matter composition of man-impacted urban sites in North Germany. J. Plant Nutr. Soil Sci. 164 (4), 359.

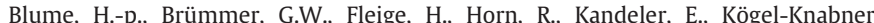
I., Kretzschmar, R., Stahr, K., Wilke, B.-M., 2016. Scheffer/Schachtschabel Soil Science. Springer Berlin Heidelberg, Berlin, Heidelberg.

Borcard, D., Gillet, F., Legendre, P., 2011. Numerical Ecology with R. Springer New York, New York, NY

Bouché, M., 1977. Lombriciens de France. Ecologie et systématique, annales de ed, INRA Editions, Paris., pp. 671

Braaker, S., Ghazoul, J., Obrist, M.K., Moretti, M., 2014. Habitat connectivity shapes urban arthropod communities: the key role of green roofs. Ecology 95 (4), $1010-1021$

Bradford, M.A., Berg, B., Maynard, D.S., Wieder, W.R., Wood, S.A., 2016. Understanding the dominant controls on litter decomposition. J. Ecol. 104 (1), 229-238.

Bretzel, F., Caudai, C., Tassi, E., Rosellini, I., Scatena, M., Pini, R., 2018. Culture and horticulture: protecting soil quality in urban gardening. Sci. Total Environ. 644, $45-51$.

Briones, M.J.I., 2014. Soil fauna and soil functions: a jigsaw puzzle. Front. Environ. Sci. 2 (April), 1-22.

Bünemann, E.K., Bongiorno, G., Bai, Z., Creamer, R.E., De Deyn, G., de Goede, R., Fleskens, L., Geissen, V., Kuyper, T.W., Mäder, P., Pulleman, M., Sukkel, W., van Groenigen, J.W., Brussaard, L., 2018. Soil quality - A critical review. Soil Biol. Biochem. 120, 105-125. https://doi.org/10.1016/j.soilbio.2018.01.030.

Butchart, S.H.M., Walpole, M., Collen, B., van Strien, A., Scharlemann, J.P.W., Almond, R.E.A., Baillie, J.E.M., Bomhard, B., Brown, C., Bruno, J., Carpenter, K.E., Carr, G.M., Chanson, J., Chenery, A.M., Csirke, J., Davidson, N.C., Dentener, F., Foster, M., Galli, A., Galloway, J.N., Genovesi, P., Gregory, R.D., Hockings, M., Kapos, V., Lamarque, J.F., Leverington, F., Loh, J., McGeoch, M.A., McRae, L., Minasyan, A., Morcillo, M.H., Oldfield, T.E.E., Pauly, D., Quader, S., Revenga, C., Sauer, J.R., Skolnik, B., Spear, D., Stanwell-Smith, D., Stuart, S.N., Symes, A., Tierney, M., Tyrrell, T.D., Vie, J.-C., Watson, R., 2010. Global biodiversity: indicators of recent declines. Science 328 (5982), 1164-1168.

Cabral, I., Keim, J., Engelmann, R., Kraemer, R., Siebert, J., Bonn, A., 2017. Ecosystem services of allotment and community gardens: a Leipzig, Germany case study. Urban For. Urban Green. 23, 44-53.

Cadisch, G., Giller, K.E., 1997. Driven by Nature: Plant Litter Quality and Decomposition.Number 631.4 I5

Campbell, C., Grayston, S., Hirst, D., 1997, jul. Use of rhizosphere carbon sources in sole carbon source tests to discriminate soil microbial communities. J. Microbiol. Methods 30 (1) 33-41.
Campbell, C.D., Chapman, S.J., Cameron, C.M., Davidson, M.S., Potts, J.M., 2003. A rapid microtiter plate method to measure carbon dioxide evolved from carbon substrate amendments so as to determine the physiological profiles of soil microbial communities by using whole soil. Appl. Environ. Microbiol. 69 (6), 3593-3599.

Cardinale, B.J., Matulich, K.L., Hooper, D.U., Byrnes, J.E., Duffy, E., Gamfeldt, L., Balvanera, P., O'Connor, M.I., Gonzalez, A., 2011. The functional role of producer diversity in ecosystems. Am. J. Bot. 98 (3), 572-592.

Carreiro, M.M., Howe, K., Parkhurst, D.F., Pouyat, R.V., 1999. Variation in quality and decomposability of red oak leaf litter along an urban-rural gradient. Biol. Fertil. Soils 30 (3), 258-268.

Caruso, T., Hammer, E.C., Hempel, S., Kohler, J., Morris, E.K., Veresoglou, S.D., Opitz, N., Wehner, J., Rillig, M.C., 2018. Assessing Soil Ecosystem Processes - Biodiversity Relationships in a Nature Reserve in Central Europe.

Ceballos, G., Ehrlich, P.R., Barnosky, A.D., Garcia, A., Pringle, R.M., Palmer, T.M., 2015. Accelerated modern human-induced species losses: entering the sixth mass extinction. Sci. Adv. 1 (5), e1400253-e1400253.

Charrier, M., Marie, A., Guillaume, D., Bédouet, L., Le Lannic, J., Roiland, C., Berland, S., Pierre, J.-S., Le Floch, M., Frenot, Y., Lebouvier, M., 2013, dec. Soil calcium availability influences shell ecophenotype formation in the sub-Antarctic land snail, Notodiscus hookeri. PLoS ONE 8 (12), e84527.

Christl, I., Gulz, P.A., Kretzschmar, R., Schulin, H.R., 2004. Umgang mit Bodenbelastungen in Familiengärten der Stadt Zürich. Technical report, ETH Zürich.

Cogger, C.G., 2005, sep. Potential compost benefits for restoration Of soils disturbed by urban development. Compost Sci. Utilization 13 (4), 243-251.

Cotrufo, M.F., De Santo, A.V., Alfani, A., Bartoli, G., De Cristofaro, A., 1995. Effects of urban heavy metal pollution on organic matter decomposition in Quercus ilex L. Woods. Environ. Pollut. 89 (1), 81-87.

Davidson, E.A., Janssens, I.A., 2006. Temperature sensitivity of soil carbon decomposition and feedbacks to climate change. Nature 440 (7081), 165-173.

Demyan, M.S., Rasche, F., Schulz, E., Breulmann, M., Müller, T., Cadisch, G., 2012. Use of specific peaks obtained by diffuse reflectance Fourier transform mid-infrared spectroscopy to study the composition of organic matter in a Haplic Chernozem. Eur. J. Soil Sci. 63 (April), 189-199.

Dorendorf, J., Wilken, A., Eschenbach, A., Jensen, K., 2015. Urban-induced changes in tree leaf litter accelerate decomposition. Ecol. Process. 4, 1-16.

Dormann, C.F., Elith, J., Bacher, S., Buchmann, C., Carl, G., Carré, G., Marquéz, J.R.G., Gruber, B., Lafourcade, B., Leitão, P.J., Münkemüller, T., McClean, C., Osborne, P.E., Reineking, B., Schröder, B., Skidmore, A.K., Zurell, D., Lautenbach, S., 2013. Collinearity: a review of methods to deal with it and a simulation study evaluating their performance. Ecography 36 (1), 27-46.

Duboc, O., Zehetner, F., Djukic, I., Tatzber, M., Berger, T.W., Gerzabek, M.H., 2012 Decomposition of European beech and Black pine foliar litter along an Alpine elevation gradient: mass loss and molecular characteristics. Geoderma 189-190, $522-531$.

Duffy, J.E., 2009. Why biodiversity is important to the functioning of real-world ecosystems. Front. Ecol. Environ. 7 (8), 437-444.

Ebeling, A., Hines, J., Hertzog, L.R., Lange, M., Meyer, S.T., Simons, N.K., Weisser, W.W., 2018. Plant diversity effects on arthropods and arthropod-dependent ecosystem functions in a biodiversity experiment. Basic Appl. Ecol. 26, 50-63.

Edmondson, J.L., Davies, Z.G., Gaston, K.J., Leake, J.R., 2014. Urban cultivation in allotments maintains soil qualities adversely affected by conventional agriculture. J. Appl. Ecol. 51 (4), 880-889.

Edmondson, J.L., Davies, Z.G., McHugh, N., Gaston, K.J., Leake, J.R., 2012. Organic carbon hidden in urban ecosystems. Sci. Report. 2, 963.

Ehrenfeld, J.G., 2003, oct. Effects of exotic plant invasions on soil nutrient cycling processes. Ecosystems 6 (6), 503-523.

Eisenhauer, N., Bowker, M.A., Grace, J.B., Powell, J.R., 2015. From patterns to causal understanding: structural equation modeling (SEM) in soil ecology. Pedobiologia $58(2-3), 65-72$

Elmqvist, T., Setälä, H., Handel, S.N., van der Ploeg, S., Aronson, J., Blignaut, J.N., Gómez-Baggethun, E., Nowak, D.J., Kronenberg, J., de Groot, R., 2015. Benefits of restoring ecosystem services in urban areas. Curr. Opin. Environ. Sustain. 14, $101-108$.

Enloe, H.A. Lockaby, B.G. Zipperer, W.C Somers, G.L, 2015. Urbanization effects on leaf litter decomposition, foliar nutrient dynamics and aboveground net primary productivity in the subtropics. Urban Ecosystems 18 (4), 1285-1303.

Evans, K.L., 2010. Individual Species and Urbanisation. Ecological Reviews, Cambridge University Press., pp. 53-87.

Fabritius, H., Ziegler, A., 2003. Analysis of $\mathrm{CaCO}_{3}$ deposit formation and degradation during the molt cycle of the terrestrial isopod Porcellio scaber (Crustacea, Isopoda). J. Struct. Biol. 142 (2), 281-291.

Finerty, G.E., de Bello, F., Bílá, K., Berg, M.P., Dias, A.T., Pezzatti, G.B., Moretti, M., 2016 Exotic or not, leaf trait dissimilarity modulates the effect of dominant species on mixed litter decomposition. J. Ecol. 104 (5), 1400-1409.

Foley, J.A., DeFries, R., Asner, G.P., Barford, C., Bonan, G., Carpenter, S.R., Chapin, F.S., Coe, M.T., Daily, G.C., Gibbs, H.K., et al. 2005. Global consequences of land use. Science 309 (5734), 570-574.

Fontana, S., Petchey, O.L., Pomati, F., 2016, may. Individual-level trait diversity concepts and indices to comprehensively describe community change in multidimensional trait space. Funct. Ecol. 30 (5), 808-818.

Francis, R.A., 2014, jan. Urban rivers: novel ecosystems, new challenges. Wiley Interdiscip. Rev, Water 1 (1), 19-29.

Frey, D., Vega, K., Zellweger, F., Ghazoul, J., Hansen, D., Moretti, M., 2018a. Predation risk shaped by habitat and landscape complexity in urban environments. J. Appl. Ecol. 55 (5), 2343-2353. 
Frey, D., Young, C., Bauer, N., Moretti, M., 2018b. A comprehensive survey of cultivated and spontaneously growing vascular plants in urban gardens. Data in Brief, under review.

Frey, D., Zanetta, A., Moretti, M., Heckmann, R., 2016. First records of Chlamydatus saltitans (Fallén, 1807) and Tupiocoris rhododendri (Dolling 1972) (Heteroptera Miridae) and notes on other rare and alien true bugs in Switzerland. Mitteilungen der Schweizerischen Entomologischen Gesellschaft 89, 51-68

García-Palacios, P., McKie, B.G., Handa, I.T., Frainer, A., Hättenschwiler, S., 2016a. The importance of litter traits and decomposers for litter decomposition: a comparison of aquatic and terrestrial ecosystems within and across biomes. Funct. Ecol. 30 (5), 819-829.

García-Palacios, P., Shaw, E.A., Wall, D.H., Hättenschwiler, S., 2016b. Temporal dynamics of biotic and abiotic drivers of litter decomposition. Ecol. Lett. 19 (5), 554-563.

García-Palacios, P., Shaw, E.A., Wall, D.H., Hättenschwiler, S., 2017. Contrasting mass-ratio vs. niche complementarity effects on litter $\mathrm{C}$ and $\mathrm{N}$ loss during decomposition along a regional climatic gradient. J. Ecol. 105 (4), 968-978.

Gaston, K.J., Davies, Z.G., Edmondson, J.L., 2010. Urban Environments and Ecosystem Functions. Ecological Reviews, Cambridge University Press., pp. 35-52.

Gessner, M.O., Swan, C.M., Dang, C.K., McKie, B.G., Bardgett, R.D., Wall, D.H., Hättenschwiler, S., 2010. Diversity meets decomposition. Trends Ecol. Evol. 25 (6), 372-380.

Gilbert, O., 1989. The Ecology of Urban Habitats. Chapmann \& Hall, London, London.

Girvan, M.S., Bullimore, J., Ball, A.S., Pretty, J.N., Osborn, A.M., 2004. Responses of active bacterial and fungal communities in soils under winter wheat to different fertilizer and pesticide regimens. Appl. Environ. Microbiol. 70 (5), 2692-2701.

Goddard, M.A., Dougill, A.J., Benton, T.G., 2010. Scaling up from gardens: biodiversity conservation in urban environments. Trends Ecol. Evol. 25 (2), 90-98.

Godefroid, S., Koedam, N., 2007. Urban plant species patterns are highly driven by density and function of built-up areas. Landsc. Ecol. 22 (8), 1227-1239.

ossner, M.M., Lewinsohn, T.M., Kahl, T., Grassein, F., Boch, S., Prati, D., Birkhofer, K., Renner, S.C., Sikorski, J., Wubet, T., Arndt, H., Baumgartner, V., Blaser, S., Blüthgen, N., Börschig, C., Buscot, F., Diekötter, T., Jorge, L.R., Jung, K., Keyel, A.C., Klein, A.M., Klemmer, S., Krauss, J., Lange, M., Müller, J., Overmann, J., Pašalić, E., Penone, C., Perović, D.J., Purschke, O., Schall, P., Socher, S.A., Sonnemann, I., Tschapka, M., Tscharntke, T., Türke, M., Venter, P.C., Weiner, C.N., Werner, M., Wolters, V., Wurst, S., Westphal, C., Fischer, M., Weisser, W.W., Allan, E., 2016. Land-use intensification causes multitrophic homogenization of grassland communities. Nature 540 (7632), 266-269.

Grime, J.P., 1998. Benefits of plant diversity to ecosystems: immediate, filter and founder effects. J. Ecol. 86 (6), 902-910.

Grimm, N.B., Faeth, S.H., Golubiewski, N.E., Redman, C.L., Wu, J., Bai, X., Briggs, J.M. 2008. Global change and the ecology of cities. Science 319 (5864), 756-760.

Groffman, P.M., Avolio, M., Cavender-Bares, J., Bettez, N.D., Grove, J.M., Hall, S.J., Hobbie, S.E., Larson, K.L., Lerman, S.B., Locke, D.H., Heffernan, J.B., Morse, J.L., Neill, C., Nelson, K.C., O’Neil-Dunne, J., Pataki, D.E., Polsky, C., Chowdhury, R.R., Trammell, T.L., 2017. Ecological homogenization of residential macrosystems. Nature Ecology and Evolution 1 (7).

Groffman, P.M., Cavender-Bares, J., Bettez, N.D., Grove, J.M., Hall, S.J., Heffernan, J.B., Hobbie, S.E., Larson, K.L., Morse, J.L., Neill, C., Nelson, K., O'Neil-Dunne, J. Ogden, L., Pataki, D.E., Polsky, C., Chowdhury, R.R., Steele, M.K., 2014. Ecological homogenization of urban USA. Front. Ecol. Environ. 12 (1), 74-81.

Grün Stadt Zurich, 2010. Biotoptypenkartierung der Stadt Zurich. Technical report.

Haase, D., Larondelle, N., Andersson, E., Artmann, M., Borgström, S., Breuste, J., GomezBaggethun, E., Gren, Å., Hamstead, Z., Hansen, R., Kabisch, N., Kremer, P., Langemeyer, J., Rall, E.L., McPhearson, T., Pauleit, S., Qureshi, S., Schwarz, N., Voigt, A. Wurster, D., Elmqvist, T., 2014. A quantitative review of urban ecosystem service assessments: concepts, models, and implementation. AMBIO 43 (4), 413-433.

Handa, I.T., Aerts, R., Berendse, F., Berg, M.P., Bruder, A., Butenschoen, O., Chauvet, E., Gessner, M.O., Jabiol, J., Makkonen, M., McKie, B.G., Malmqvist, B., Peeters, E.T.H.M., Scheu, S., Schmid, B., van Ruijven, J., Vos, V.C.a., Hättenschwiler, S., 2014 Consequences of biodiversity loss for litter decomposition across biomes. Nature 509 (7499), 218-221.

Hansen, A.J., Knight, R.L., Marzluff, J.M., Powell, S., Brown, K., Gude, P.H., Jones, K., 2005, dec. Effects of exurban development on biodiversity: patterns, mechanisms, and research needs. Ecol. Appl. 15 (6), 1893-1905.

Hättenschwiler, S., Gasser, P., 2005. Soil animals alter plant litter diversity effects on decomposition. Proc. Natl. Acad. Sci. 102 (5), 1519-1524.

Hättenschwiler, S., Tiunov, A.V., Scheu, S., 2005. Biodiversity and litter decomposition in terrestrial ecosystems. Annu. Rev. Ecol. Evol. Syst. 36 (1), 191-218.

Hausser, J., 2005. Clé de détermination des Gastéropodes de Suisse. Centre suisse de cartographie de la faune, Neuchâtel.

Hector, A., Bagchi, R., 2007. Biodiversity and ecosystem multifunctionality. Nature 448 (7150), 188-190.

Heemsbergen, D.A., 2004. Biodiversity effects on soil processes explained by interspecific functional dissimilarity. Science 306 (5698), 1019-1020.

Hinchliff, C.E., Smith, S.A., Allman, J.F., Burleigh, J.G., Chaudhary, R., Coghill, L.M., Crandall, K.A., Deng, J., Drew, B.T., Gazis, R., Gude, K., Hibbett, D.S., Katz, L.A., Laughinghouse, H.D., McTavish, E.J., Midford, P.E., Owen, C.L., Ree, R.H., Rees, J.A., Soltis, D.E., Williams, T., Cranston, K.A., 2015. Synthesis of phylogeny and taxonomy into a comprehensive tree of life. Proc. Natl. Acad. Sci. 112 (41) 12764-12769.

Hooper, D.U., Chapin, F.S., Ewel, J.J., Hector, A., Inchausti, P., Lavorel, S., Lawton, J.H., Lodge, D.M., Loreau, M., Naeem, S., Schmid, B., Setälä, H., Symstad, A.J., Vandermeer, J., Wardle, D.A., 2005. Effects of biodiversity on ecosystem functioning: a consensus of current knowledge. Ecol. Monogr. 75 (1), 3-35.
Inman, J.C., Parker, G., 1978. Decomposition and heavy metal dynamics of forest litter in Northwestern Indiana. Environ. Pollut. (1970) 17 (1), 39-51.

Isbell, F., Gonzalez, A., Loreau, M., Cowles, J., Díaz, S., Hector, A., Mace, G.M., Wardle, D.A., O'Connor, M.I., Duffy, J.E., Turnbull, L.A., Thompson, P.L., Larigauderie, A., 2017. Linking the influence and dependence of people on biodiversity across scales. Nature 546 (7656), 65-72.

Ives, C.D., Lentini, P.E., Threlfall, C.G., Ikin, K., Shanahan, D.F., Garrard, G.E., Bekessy, S.A., Fuller, R.A., Mumaw, L., Rayner, L., Rowe, R., Valentine, L.E., Kendal, D., 2016 Cities are hotspots for threatened species. Glob. Ecol. Biogeogr. 25 (1), 117-126.

Janik, L.J., Skjemstad, J.O., Shepherd, K.D., Spouncer, L.R., 2007. The prediction of soil carbon fractions using mid-infrared-partial. Aust. J. Soil Res. 45, 73-81.

Kabisch, N., Haase, D., 2013. Green spaces of European cities revisited for 1990-2006. Landsc. Urban Plan. 110 (1), 113-122.

Kabuyah, R.N., van Dongen, B.E., Bewsher, A.D., Robinson, C.H., 2012. Decomposition of lignin in wheat straw in a sand-dune grassland. Soil Biol. Biochem. 45, 128-131.

Kaye, J., Groffman, P.M., Grimm, N.B., Bake, L., Pouyat, R.V., 2006. A distinct urban biogeochemistry? Trends Ecol. Evol. 21 (4), 192-199.

Keniger, L.E., Gaston, K.J., Irvine, K.N., Fuller, R.A., 2013. What are the benefits of interacting with nature? Int. J. Environ. Res. Public Health 10 (3), 913-935.

Kida, K., Kawahigashi, M., 2015. Influence of asphalt pavement construction processes on urban soil formation in Tokyo. Soil Sci. Plant Nutr. 61 (sup1), 135-146.

Korner-Nievergelt, F., Roth, T., Von Felten, S., Guélat, J., Almasi, B., Korner-Nievergelt, P., 2015. Bayesian Data Analysis in Ecology Using Linear Models With R, BUGS, and Stan. Academic Press.

Kottek, M., Grieser, J., Beck, C., Rudolf, B., Rubel, F., 2006. World Map of the Köppen-Geiger climate classification updated. Meteorol. Z. 15 (3), 259-263.

Kühn, I., Brandl, R., Klotz, S., 2004. The flora of German cities is naturally species rich. Evol. Ecol. Res. 6 (5), 749-764.

Kunlanit, B., Vityakon, P., Puttaso, A., Cadisch, G., Rasche, F., 2014, sep. Mechanisms controlling soil organic carbon composition pertaining to microbial decomposition of biochemically contrasting organic residues: evidence from midDRIFTS peak area analysis. Soil Biol. Biochem. 76, 100-108.

Laliberté, E., Legendre, P., 2010. A distance-based framework for measuring functional diversity from multiple traits. Ecology 91 (1), 299-305.

Lavelle, P., Decaëns, T., Aubert, M., Barot, S., Blouin, M., Bureau, F., Margerie, P., Mora, P., Rossi, J.-P., 2006. Soil invertebrates and ecosystem services. Eur. J. Soil Biol. 42 (SUPPL. 1), S3-S15.

Lawrence, A.P., Bowers, M.A., 2002. A test of the 'hot' mustard extraction method of sampling earthworms. Soil Biol. Biochem. 34 (4), 549-552.

Lefcheck, J.S., 2016. piecewiseSEM: piecewise structural equation modelling in $r$ for ecology, evolution, and systematics. Methods Ecol. Evol. 7 (5), 573-579.

Lin, B.B., Egerer, M.H., 2018. Urban agriculture: an opportunity for biodiversity and food provision in urban landscapes. Urban Biodiversity: From Research to Practice. Routledge, London, pp. 85-100.

Lin, B.B., Philpott, S.M., Jha, S., Liere, H., 2017. Urban agriculture as a productive green infrastructure for environmental and social well-being. Greening Cities Forms and Functions. Springer, Singapore, pp. 155-179.

Loram, A., Tratalos, J., Warren, P.H., Gaston, K.J., 2007. Urban domestic gardens (X): the extent \& structure of the resource in five major cities. Landsc. Ecol. 22 (4), 601-615

Lorenz, K., Lal, R., 2009. Biogeochemical C and N cycles in urban soils. Environ. Int. 35 (1), 1-8.

Lusk, M.G., Toor, G.S., 2018. Optimizing the hydrologic properties of urban soils. In: Stewart, B.A., Lal, R. (Eds.), Urban soils. Boca Raton: CRC Press.

Magurran, A.E., McGill, B.J., 2011. Biological Diversity: Frontiers in Measurement and Assessment. Oxford University Press.

Mata, L., Threlfall, C.G., Williams, N.S.G., Hahs, A.K., Malipatil, M., Stork, N.E., Livesley, S.J., 2017. Conserving herbivorous and predatory insects in urban green spaces. Sci. Report. 7, 40970.

McClaugherty, C., Berg, B., 2011. Soils and decomposition. eLS (September), 1-8.

McDonnell, M., Pickett, S.T.A., Groffman, P., Bohlen, P., Pouyat, R., Zipperer, W., Carreiro, M., Medley, K., 1997. Ecosystem processes along an urban to rural gradient. Urban Ecosystems 1, 21-36.

McKinney, M.L., 2008, jun. Effects of urbanization on species richness: a review of plants and animals. Urban Ecosystems 11 (2), 161-176.

Melliger, R.L., Rusterholz, H.-P., Baur, B., 2017, oct. Habitat- and matrix-related differences in species diversity and trait richness of vascular plants, Orthoptera and Lepidoptera in an urban landscape. Urban Ecosystems 20 (5), 1095-1107.

MeteoSwiss, 2017. Klimanormwerte Zürich Fluntern Normperiode 1981-2010. Technical report.

Michonneau, F., Brown, J.W., Winter, D.J., 2016. rotl: an R package to interact with the Open Tree of Life data. Methods Ecol. Evol. 7 (12), 1476-1481.

Nakagawa, S., Schielzeth, H., 2013. A general and simple method for obtaining R2 from generalized linear mixed-effects models. Methods Ecol. Evol. 4 (2), 133-142.

Nault, J.R., Preston, C.M., Trofymow, J.A.T., Fyles, J., Kozak, L., Siltanen, M., Titus, B., 2009. Applicability of diffuse reflectance Fourier transform infrared spectroscopy to the chemical analysis of decomposing foliar litter in Canadian forests. Soil Sci. 174 (3), 130-142.

Nielsen, U.N., Ayres, E., Wall, D.H., Bardgett, R.D., 2011. Soil biodiversity and carbon cycling: a review and synthesis of studies examining diversity-function relationships. Eur. J. Soil Sci. 62 (1), 105-116.

Nikula, S., Vapaavuori, E., Manninen, S., 2010. Urbanization-related changes in European aspen (Populus tremula L.): Leaf traits and litter decomposition. Environ. Pollut. 158 (6), 2132-2142.

Oke, T.R., 1995. The Heat Island of the Urban Boundary Layer: Characteristics, Causes and Effects. Springer Netherlands, Dordrecht., pp. 81-107. 
Oksanen, J., Blanchet, F., Kindt, R., Legendre, P., Minchin, P., O’hara, R., Simpson, G., Solymos, P., Stevens, M.H.H., Wagner, H., 2016. vegan: Community Ecology Package. R package version 2.4-1.

Ossola, A., Irlich, U.M., Niemelä, J., 2018. Bringing Urban Biodiversity Research Into Practice. Routledge, London.

Paradis, E., 2011. Analysis of Phylogenetics and Evolution With R. Springer New York, New York, NY

Paradis, E., Claude, J., Strimmer, K., 2004. APE: analyses of phylogenetics and evolution in R language. Bioinformatics 20 (2), 289-290.

Pardee, G.L., Philpott, S.M., 2014. Native plants are the bee's knees: local and landscape predictors of bee richness and abundance in backyard gardens. Urban Ecosystems 17 (3), 641-659.

Parlow, E., Scherer, D., Fehrenbach, U., 2010. Klimaanalyse der Stadt Zürich (KLAZ) Wissenschaftlicher Bericht. Technical report.

Patoine, G., Thakur, M.P., Friese, J., Nock, C., Hönig, L., Haase, J., Scherer-Lorenzen, M., Eisenhauer, N., 2017. Plant litter functional diversity effects on litter mass loss depend on the macro-detritivore community. Pedobiologia 65 (April), 29-42.

Pavao-Zuckerman, M.A., Coleman, D.C., 2005, jul. Decomposition of chestnut oak (Quercus prinus) leaves and nitrogen mineralization in an urban environment. Biol. Fertil. Soils 41 (5), 343-349.

Pebesma, E.J., 2004. Multivariable geostatistics in S: the gstat package. Comput. Geosci. 30 (7), 683-691.

Pérez-Harguindeguy, N., Diaz, S., Garnier, E., Lavorel, S., Poorter, H., Jaureguiberry, P., Bret-Harte, M.S., Cornwell, W.K., Craine, J.M., Gurvich, D.E., Urcelay, C., Veneklaas, E.J., Reich, P.B., Poorter, L., Wright, I.J., Etc., Ray, P., Etc., Díaz, S., Lavorel, S., Poorter, H., Jaureguiberry, P., Bret-Harte, M.S., Cornwell, W.K., Craine, J.M., Gurvich, D.E., Urcelay, C., Veneklaas, E.J., Reich, P.B., Poorter, L., Wright, I.J., Ray, P., Enrico, L., Pausas, J.G., de Vos, A.C., Buchmann, N., Funes, G., Quétier, F., Hodgson, J.G., Thompson, K., Morgan, H.D., ter Steege, H., van der Heijden, M.G.A., Sack, L., Blonder, B., Poschlod, P., Vaieretti, M.V., Conti, G., Staver, A.C., Aquino, S., Cornelissen, J.H.C., 2013. New handbook for standardized measurement of plant functional traits worldwide. Aust. J. Bot. 61 (34), 167-234.

Pinheiro, J., Bates, D., DebRoy, S., Sarkar, D., Core Team, R., 2018. \{nlme\}: Linear and Nonlinear Mixed Effects Models.

Popescu, A.-A., Huber, K.T., Paradis, E., 2012. ape 3.0: new tools for distance-based phylogenetics and evolutionary analysis in R. Bioinformatics 28 (11), 1536-1537.

Pouyat, R.V., Carreiro, M.M., 2003. Controls on mass loss and nitrogen dynamics of oak leaf litter along an urban-rural land-use gradient.. Oecologia 135 (2), 288-298.

Pouyat, R.V., McDonnell, M.J., Pickett, S.T.A., 1997. Litter decomposition and nitrogen mineralization in oak stands along an urban-rural land use gradient. Urban Ecosystems 1 (2), 117-131.

Querner, P., Bruckner, A., 2010. Combining pitfall traps and soil samples to collect Collembola for site scale biodiversity assessments. Appl. Soil Ecol. 45 (3), 293-297.

Rasche, F., Marhan, S., Berner, D., Keil, D., Kandeler, E., Cadisch, G., 2013. midDRIFTS-based partial least square regression analysis allows predicting microbial biomass, enzyme activities and 16S rRNA gene abundance in soils of temperate grasslands. Soil Biol. Biochem. 57, 504-512.

Rawlins, B.G., Harris, J., Price, S., Bartlett, M., 2015. A review of climate change impacts on urban soil functions with examples and policy insights from England, UK. Soil Use Manag. 31 (September), 46-61.

Rebele, F., 1994. Urban ecology and special features of urban ecosystems. Glob. Ecol. Biogeogr. Lett. 173-187.

Rodriguez, S.G.S., 2011. Particulate and Organic Matter Fouling of Seawater Reverse Osmosis Systems: Characterization, Modelling and Applications. CRC Press.

Rusek, J., 1998. Biodiversity of Collembola and their functional role in the ecosystem. Biodivers. Conserv 7 (9), 1207-1219.

Sattler, T., Duelli, P., Obrist, M.K., Arlettaz, R., Moretti, M., 2010. Response of arthropod species richness and functional groups to urban habitat structure and management. Landsc. Ecol. 25 (6), 941-954.

Schram-Bijkerk, D., Otte, P., Dirven, L., Breure, A.M., 2018. Indicators to support healthy urban gardening in urban management. Sci. Total Environ. 621, 863-871.

Schwarz, N., Moretti, M., Bugalho, M.N., Davies, Z.G., Haase, D., Hack, J., Hof, A., Melero, Y., Pett, T.J., Knapp, S., 2017. Understanding biodiversity-ecosystem service relationships in urban areas: a comprehensive literature review. Ecosyst. Serv. 27, $161-171$.

Seastedt, T.R., 1984. The role of microarthropods in decomposition and mineralization processes. Annu. Rev. Entomol. 29 (1), 25-46.

Senesi, N., D'orazio, V., Ricca, G., 2003. Humic acids in the first generation of EUROSOILS. Geoderma 116 (3), 325-344.

Shipley, B., 2016. Cause and Correlation in Biology: A User's Guide to Path Analysis, Structural Equations and Causal Inference With R. Cambridge University Press.

Siepel, H., Maaskamp, F., 1994. Mites of different feeding guilds affect decomposition of organic matter. Soil Biol. Biochem. 26 (10), 1389-1394.
Sims, R.W. Gerard, B.M. 1999. Earthworms: Notes for the Identification of British Species. Linnean Society of London and the Estuarine and Coastal Sciences Association.

Smidt, E., Meissl, K., 2007. The applicability of Fourier transform infrared (FT-IR) spectroscopy in waste management. Waste Manag. 27 (2), 268-276.

Smith, R.M., Warren, P.H., Thompson, K.E.N., Gaston, K.J., 2006. Urban domestic gardens (VI): environmental correlates of invertebrate species richness. Biol. Conserv. 15 (8), 2415-2438.

Sradnick, A., Murugan, R., Oltmanns, M., Raupp, J., Joergensen, R.G., 2013. Changes in functional diversity of the soil microbial community in a heterogeneous sandy soil after long-term fertilization with cattle manure and mineral fertilizer. Appl. Soil Ecol. 63, 23-28.

Stevenson, F.J., 1994. Humus Chemistry: Genesis, Composition, Reactions. John Wiley \& Sons.

Swift, M.J., Heal, O.W., Anderson, J.M., 1979. Decomposition in Terrestrial Ecosystems. Univ of California Press.

Tappert, S., Klöti, T., Drilling, M., 2018. Contested urban green spaces in the compact city: the (re-)negotiation of urban gardening in Swiss cities. Landsc. Urban Plan. 170 (May 2017), 69-78.

Tatzber, M., Mutsch, F., Mentler, A., Leitgeb, E., Englisch, M., Gerzabek, M.H., 2010. Determination of organic and inorganic carbon in forest soil samples by midinfrared spectroscopy and partial least squares regression. Appl. Spectrosc. 64 (10), $1167-1175$

Tresch, S., Moretti, M., Le Bayon, R.-C., Mäder, P., Zanetta, A., Frey, D., Fliessbach, A., 2018a. A gardener's influence on urban soil quality. Front. Environ. Sci. 6 (MAY).

Tresch, S., Moretti, M., Le Bayon, R.-C., Mäder, P., Zanetta, A., Frey, D., Stehle, B., Kuhn, A., Munyangabe, A., Fliessbach, A., 2018b. Urban soil quality assessment-a comprehensive case study dataset of urban garden soils. Front. Environ. Sci. 6 (November), 1-5.

UN FAO, 2011. Payments for Ecosystem Services and Food Security. Office of Knowledge Exchange, Research and Extension, Rome.

United Nations, 2015. World Urbanization Prospects: The 2014 Revision. Technical report, Department of Economic and Social Affairs, Population Division.

Vauramo, S., Setälä, H., 2011. Decomposition of labile and recalcitrant litter types under different plant communities in urban soils. Urban Ecosystems 14 (1), 59-70.

Villéger, S., Mason, N.W.H., Mouillot, D., 2008, aug. New multidimensional functional diversity indices for a multifaceted framework in functional ecology. Ecology 89 (8), 2290-2301.

Vogel, A., Eisenhauer, N., Weigelt, A., Scherer-Lorenzen, M., 2013. Plant diversity does not buffer drought effects on early-stage litter mass loss rates and microbial properties. Glob. Chang. Biol. 19 (9), 2795-2803.

Vos, V.C.A, van Ruijven, J., Berg M.P., Peeters, E.T.H.M., Berendse, F., 2011. Macrodetritivore identity drives leaf litter diversity effects. Oikos 120 (7), 1092-1098.

Wardle, D.A., Bardgett, R.D., Callaway, R.M., Van der Putten, W.H., 2011. Terrestrial ecosystem responses to species gains and losses. Science 332 (6035), 1273-1277.

Watanabe, S., 2010. Asymptotic equivalence of Bayes cross validation and widely applicable information criterion in singular learning theory. J. Mach. Learn. Res. 11 (Dec), 3571-3594.

Weisser, W.W., Roscher, C., Meyer, S.T., Ebeling, A., Luo, G., Allan, E., Beßler, H., Barnard, R.L., Buchmann, N., Buscot, F., Engels, C., Fischer, C., Fischer, M., Gessler, A., Gleixner, G., Halle, S., Hildebrandt, A., Hillebrand, H., de Kroon, H., Lange, M., Leimer, S., Le Roux, X., Milcu, A., Mommer, L., Niklaus, P.A., Oelmann, Y. Proulx, R., Roy, J., Scherber, C., Scherer-Lorenzen, M., Scheu, S., Tscharntke, T., Wachendorf, M., Wagg, C., Weigelt, A., Wilcke, W., Wirth, C., Schulze, E.-D., Schmid, B., Eisenhauer, N., 2017. Biodiversity effects on ecosystem functioning in a 15-year grassland experiment: patterns, mechanisms, and open questions. Basic Appl. Ecol. 23, 1-73.

Zaller, J.G., 2018. Unser Täglich Gift. Deuticke, Wien.

Zhou, W., Pickett, S.T.A., Cadenasso, M.L., 2017. Shifting concepts of urban spatial heterogeneity and their implications for sustainability. Landsc. Ecol. 32 (1), 15-30.

Zhu, W., Egitto, B., Yesilonis, I.D., Pouyat, R., 2018. Soil carbon and nitrogen cycling and ecosystem service in cities. In: Stewart, B.A., Lal, R. (Eds.), Urban soils. Boca Raton: CRC Press, Boca Raton.

Ziter, C., 2016, jun. The biodiversity-ecosystem service relationship in urban areas: a quantitative review. Oikos 125 (6), 761-768.

Ziter, C., Turner, M.G., 2018. Current and historical land use influence soil-based ecosystem services in an urban landscape. Ecol. Appl. 28 (3), 643-654. 